\title{
THE ADEQUACY OF LIFE INSURANCE: \\ EVIDENCE FROM THE HEALTH AND RETIREMENT SURVEY
}

\author{
B. Douglas Bernheim \\ Lorenzo Forni \\ Jagadeesh Gokhale \\ Laurence J. Kotlikoff
}

Working Paper 7372

http://www.nber.org/papers/w7372

\author{
NATIONAL BUREAU OF ECONOMIC RESEARCH \\ 1050 Massachusetts Avenue \\ Cambridge, MA 02138 \\ October 1999
}

We thank the National Institute of Aging for research support and Economic Security Planning, Inc. for permitting the use of Economic Security Planner (ESPlanner) in this study. The opinions expressed here are those of the authors and not necessarily those of the Federal Reserve Bank of Cleveland, The Bank of Italy, Economic Security Planning, Inc., Boston University, Stanford University, or the National Bureau of Economic Research.

(C) 1999 by B. Douglas Bernheim, Lorenzo Forni, Jagadeesh Gokhale, and Laurence J. Kotlikoff. All rights reserved. Short sections of text, not to exceed two paragraphs, may be quoted without explicit permission provided that full credit, including $(\mathbb{C}$ notice, is given to the source. 
The Adequacy of Life Insurance: Evidence from the Health and Retirement Survey

B. Douglas Bernheim, Lorenzo Forni, Jagadeesh Gokhale, and Laurence J. Kotlikoff

NBER Working Paper No. 7372

October 1999

JEL No. G22

\section{ABSTRACT}

This study examines the adequacy of life insurance among married American couples approaching retirement. It improves upon previous work in two ways. First, it is based on recent, high quality data (the 1992 Health and Retirement Survey with matched Social Security earnings histories). Second, it employs new financial planning software to evaluate the life insurance needs of each household. This software embodies an elaborate life-cycle planning model that accounts for a broad array of demographic, economic, and financial characteristics.

We find that a sizable minority of couples in the HRS sample are significantly underinsured. Almost one third of wives and more than 10 percent of husbands would have suffered living standard reductions of 20 percent or more had their spouses died in 1992. Underinsurance tends to be more common among low income households, couples with asymmetric earnings, younger households, couples with dependent children, and non-whites. In general, households with greater vulnerabilities do not appear to compensate adequately for these vulnerabilities through greater life insurance holdings. Among some groups, the frequency of underinsurance exceeds two-thirds, and the frequency of severe underinsurance (a reduction in living standard of 40 percent or greater) exceeds one-quarter.

B. Douglas Bernheim

Department of Economics

Stanford University

Stanford, CA 94305-6072

and NBER

bernheim@leland.stanford.edu

Jagadeesh Gokhale

Federal Reserve Bank of Cleveland

1455 East 6th Street

Cleveland, $\mathrm{OH} 44101$

ajgokhale@stratos.net
Lorenzo Forni

Department of Economics

Boston University

270 Bay State Rd.

Boston, MA 02215

Iforni@bu.edu

Laurence J. Kotlikoff

Department of Economics

Boston University

270 Bay State Rd.

Boston, MA 02215

and NBER

kotlikof@bu.edu 


\section{Introduction}

Several previous studies suggest that many American households purchase insufficient insurance to safeguard themselves against the risk of economic loss due to the death of a primary breadwinner. Auerbach and Kotlikoff $[1987,1991$ a] use the Retirement History Survey and conclude that a significant minority of households nearing or in retirement in the late 1960 s had inadequate life insurance. Moreover, almost one-half of households at risk (those for whom a significant portion of household resources take the form of earnings and benefits that cease with the death of the husband or wife) were inadequately insured. As a result of this insurance shortfall, the authors predict that roughly one-third of older wives in their sample would have experienced a 25 percent or greater reduction in their living standards had their husbands died during the survey year. The predicted reduction in living standard is more severe for younger widows and widows whose husbands had higher earnings, indicating a greater insurance shortfall for these groups.

Auerbach and Kotlikoff [1991b] examine the adequacy of life insurance for middle-aged households using SRI International data from the early 1960s. They too find that a significant minority of wives were highly underinsured with respect to the possible deaths of their husbands; roughly 25 to 30 percent of the survey's wives would have suffered a reduction in standard of living in excess of 30 percent had their husbands died during the survey year. Among couples with greater life insurance needs (those for whom the expected present value of household resources would have declined by at least 50 percent upon the husband's death), this figure is significantly higher - between 30 and 40 percent.

Other studies have reached similar conclusions. Hurd and Wise [1989] consider the high incidence of poverty among widows, and demonstrate that a widow's poverty status often arises as the direct result of her husband's death. They point out that, whereas only 9 percent of their sample of couples (in which the husband subsequently dies) were poor, approximately 35 percent of subsequent widows were poor. Holden, Burkhauser, and Myers [1986] also document the decline in living standard for surviving widows.

Although the aforementioned studies are very informative, they suffer from several shortcomings. 
First, most use rather old data. Obviously, the adequacy of life insurance during the 1960s may shed little light on current behavior. Second, prior studies do not account for many critical factors that determine insurance needs, such as the numbers and ages of dependent children, economies of scale in shared living, liquidity constraints, and the non-fungibility of housing. Third, previous investigators did not have access to reliable information on past income streams, which are critical for determining both permanent income and for computing Social Security retirement and survivor benefits.

The current study reexamines the adequacy of life insurance among married American households approaching retirement. It overcomes the shortcomings mentioned in the previous paragraph in two ways. First, it uses the first wave of the Health and Retirement Survey (HRS), which provides extensive information on roughly 7,500 households whose heads or spouses were between 51 and 61 years old in 1992. The HRS is linked to a supplemental data set containing Social Security earnings histories.' Second, the current study evaluates the life insurance needs of each household using a new financial planning software package, Economic Security Planner (ESPlanner), which was developed separately by three of the four authors of this paper. This software embodies an elaborate life cycle planning model that accounts for a broad array of demographic, economic, and financial factors not included in previous research. ${ }^{2}$ The program computes the highest sustainable living standard for each household as well as the levels of saving and insurance required to achieve this living standard. In so doing, it takes account of liquidity constraints, the illiquidity of housing, and special ("off-the-top") household expenditure requirements.

For the purposes of this study, we consider the level of life insurance to be adequate if it allows an individual and his or her children to sustain his or her living standard upon the death of a spouse. It is important to emphasize that we do not equate adequacy with rationality. A couple might purchase relatively

\footnotetext{
${ }^{1}$ We have used this supplemental data set in compliance with confidentiality requirements and security restrictions.

${ }^{2}$ Economic Security Planning, Inc. provides free copies of the program for academic research.
} 
little life insurance for a variety of economically legitimate reasons. For example, the household's decision maker(s) may place relatively little weight on the well-being of the secondary earner, or may regard life insurance as excessively expensive. Thus, the current study is not intended to shed light on the rationality of life insurance purchases. Instead, our objective is descriptive: we seek to quantify the extent of uninsured financial vulnerabilities both for the population as a whole, as well as for subgroups that are at the greatest risk.

Our central findings may be summarized as follows: More than half of wives in the HRS sample are inadequately protected against the deaths of their husbands. We predict that roughly 15 percent of wives would have suffered a reduction in living standard of 40 percent or greater (defined as "severe underinsurance"), and another 15 percent of wives would have suffered a reduction in living standard of 20 to 40 percent (defined as "significant underinsurance"), had their husbands died in the survey year. These figures are slightly higher for individuals classified as secondary earners. In contrast, roughly one-quarter of husbands are inadequately protected against the deaths of their wives; only 5 percent are severely underinsured, and only 6 percent are significantly underinsured.

Underinsurance tends to decline with household income at low levels of income, and then to level off at moderate levels of income. However, among some groups, the degree of underinsurance -- the frequency of severe underinsurance - increases with income. For example, more than one-quarter of secondary earners in households with incomes of at least $\$ 100,000$ are severely underinsured.

Non-earners in single-earner households are particularly vulnerable, and couples do not increase their insurance purchases adequately to compensate for these vulnerabilities. More than one in five non-earners is severely underinsured, and roughly another one in seven is significantly underinsured. More generally, when secondary earners (defined to include non-earners) bring in less than 25 percent of primary earnings, nearly one secondary earner in four is severely underinsured.

Younger households are also more vulnerable than older households, since they have greater human 
capital to protect. Nevertheless, younger individuals do not adequately compensate for these greater vulnerabilities. The frequency of underinsurance exceeds 70 percent for 40 -something secondary earners, and nearly half of this group is either significantly or severely underinsured. In contrast, the frequency of underinsurance is just over one-third for 60 -something secondary earners, and only 26 percent of this group is significantly or severely underinsured.

Households with dependent children are also more vulnerable than childless couples or couples with adult children. Nevertheless, those with children do not adequately compensate for their greater vulnerabilities. More than two-thirds of secondary earners in households with dependent children are underinsured, compared with just over one-half of all other households. Nearly half of secondary earners in households with dependent children are significantly underinsured, and more than one-quarter are severely underinsured. The comparable figures for other households are much lower.

We document a strong relationship between underinsurance and ethnicity. Comparing non-whites to whites, the frequency of severe underinsurance is more than three times as high among non-white husbands, and nearly twice as high for non-white wives. Among non-white households, more than one secondary earner in four is severely underinsured, and nearly half are significantly or severely underinsured.

We derive the aforementioned results from simple tabulations. We also use quantile regressions to describe the way in which demographics and other factors independently affect the population distribution of the predicted change in living standard resulting from a spouse's death. The predicted decline in an individual's standard of living is correlated positively with the spouse's share of household earnings, negatively with age and spouse's age (among wives and secondary earners), positively with number of dependents (among husbands), positively with a "non-white" dummy variable, negatively with the household head's educational status (among wives and secondary earners), negatively with pension eligibility (among wives and secondary earners), negatively with spouse's pension eligibility (among husbands and primary earners), and negatively with home ownership. In many cases, these effects are strongest among the fraction 
of the population that is least well insured (that is, at the 25 th percentile), and weakest among the fraction of the population that is best insured (at the 75 th percentile). This suggests that well-insured individuals better appreciate the relationships between household characteristics and insurance needs. In many cases, the effects are also stronger for wives and secondary earners than for husbands and primary earners. There is little evidence that the predicted decline in living standard is related to subjective survival probabilities. Consequently, one cannot attribute instances of apparent underinsurance to optimism concerning longevity. Neither earnings nor assets appear to have strong independent effects on insurance adequacy.

Using these quantile regression results, we compute fitted distributions for the impact of a spouse's death for population subgroups with particular combinations of characteristics (in particular, a representative base case, and a highly vulnerable case). Among the highly vulnerable group, nearly one-quarter of wives and more than one-quarter of secondary earners would have insufficient resources to cover fixed, "off-the-top" expenditures after their spouses' deaths. The median wife and secondary earner within this group would experience more than a 50 percent decline in living standard. Characteristics that are associated with underinsurance are shown to create downward skewness in the distribution of the projected impact of a spouse's death. For husbands and primary earners, the median projected impact of a spouse's death is small even within the highly vulnerable group. However, more than one-quarter of highly vulnerable husbands would experience living standard declines of 50 percent or greater.

The remainder of the paper is organized as follows. We describe our methodology in Section 2 and our data in Section 3. Section 4 contains results, including tabular summaries and descriptive quantile regressions. Section 5 concludes.

\section{Methodology}

Strictly speaking, the adequacy of a household's life insurance is in the eyes of the beholder. Virtually any level of life insurance can be rationalized as reflecting the maximization of some intertemporal and state- 
specific preference function. Nevertheless, we think it possible to establish meaningful benchmarks and to evaluate the adequacy of insurance in comparison to these benchmarks. In so doing, it is important to emphasize that significant deviations from the benchmarks do not necessarily reflect irrationality. Rather, they simply indicate the extent to which actual choices either fall short of or exceed some easily interpreted target. ${ }^{3}$

For the purposes of this study, we adopt the same benchmark as Auerbach and Kotlikoff (1987): life insurance is defined to be adequate if the survivor's highest sustainable standard of living after the death of a spouse is equal to or greater than the couple's highest sustainable standard of living if both survive. We equate standard of living with consumption, adjusted for household demographic composition. In other words, insurance adequacy, in the sense that we use the term here, is associated with demographically-adjusted consumption smoothing across the states of nature associated with the survival or death of the covered spouse. When we say that an individual is inadequately insured, this means that his or her highest sustainable standard of living would decline upon the death of his or her spouse. It's worth reiterating that we do not necessarily equate underinsurance with irrationality. Regardless of what explains underinsurance, its frequency and severity sheds considerable light on financial vulnerability. It helps us to understand, for example, why such a large fraction of elderly widows end up in poverty.

Separately from the current study, three of the authors have developed a life-cycle financial planning software package, Economic Security Planner, that can be used for computing each household's benchmark for life insurance adequacy. Given detailed information on demographic, economic, and financial characteristics, the model computes the household's highest sustainable living standard, as well as the levels of saving and insurance required to achieve this living standard. ${ }^{4}$

To understand the objective function in more formal terms, imagine maximizing an intertemporally

\footnotetext{
${ }^{3}$ It is important to add that significant deviations from the benchmarks may also reflect mismeasured data, or unmeasured special characteristics.

${ }^{4}$ There are several important differences between the approach used here and that of Auerbach and Kotlikoff (1987). For example, in the current paper we account for liquidity constraints, adjust consumption for changes in household composition, and treat state and federal taxes and Social Security benefits in much greater detail.
} 
separable, homothetic (isoelastic) utility function defined over levels of consumption that are adjusted (as detailed below) to reflect household composition, subject to resource constraints, liquidity constraints, and nonnegativity constraints on life insurance purchases. ${ }^{5}$ The software identifies the limit of solutions to this maximization problem as the intertemporal elasticity of substitution approaches zero. ${ }^{6}$ In so doing, the software smoothes the household's standard of living to the extent permitted by the household's constraints on borrowing. Smoothing a household's living standard is not necessarily the same as smoothing its consumption expenditures. If the household's living standard is smooth, but its demographic composition changes from year to year, maintaining a constant living standard for those remaining in the household will entail changing the level of consumption expenditures.

Although a complete description of the underlying model would be prohibitively lengthy, it is important to summarize the ways in which we account for several critical demographic, economic, and financial factors.

\section{Household Composition}

The benchmark financial plan for each couple depends critically on the ages of the husband and wife, as well as on the number and ages of all dependent children. The husband and wife are assumed to remain members of the household until their deaths, which occurs no later than some maximum age of life (set equal to 95 for all of our calculations). Children are included as members of the household through and including age 18 .

${ }^{5}$ The non-negativity constraint for life insurance reflects the implicit assumption that annuities are not available for purchase at the margin. For further discussion, see Yaari (1965), Kotlikoff and Spivak (1981), and Bernheim (1987).

${ }^{6}$ Note that we think of the software as computing the limit of solutions as the intertemporal elasticity of substitution approaches zero, rather than the solution with an intertemporal elasticity of substitution equal to zero. The limiting case corresponds to Leontief preferences. At the limit, the household is indifferent about the distribution of resources across any years in which its standard of living exceeds its minimum level. This often implies that the solution is not unique (indeed, the number of solutions may be uncountably infinite). However, this problem does not arise as one approaches the limit. 
The composition of the household affects the standard of living associated with any given level of consumption at any given point in time. We assume that an expenditure of $(\mathrm{N}+\beta \mathrm{K})^{\alpha} \mathrm{C}$, when there are $\mathrm{N}$ adults and $\mathrm{K}$ children in the household, provides for the same standard of living as an expenditure of $\mathrm{C}$ when there is only one adult in the household. The coefficient $\beta$ reflects an adult equivalency scale; it implies that the addition of a child to the household has the same effect on standard of living as the addition of $\beta$ additional adults (where $\beta$ would typically be less than unity). For our calculations, we assume that $\beta=0.5$, which is consistent with the existing empirical literature. ${ }^{7}$ Our analysis thereby accounts for the fact that a lower level of spending is needed to achieve the same standard of living once children leave the household. The exponent $\alpha$ captures economies of scale in shared living. If $\alpha$ equals 1 , there are no economies in shared living; if $\alpha$ equals zero there are perfect economies in shared living. For higher values of $\alpha$, actual insurance holdings will appear more adequate; for lower values of $\alpha$, they will appear less adequate. In this study, we set $\alpha$ to 0.678 , implying that for going from a household of one to two adults, expenditures must increase by a factor of 1.6 in order to preserve the same living standard per household member. This value appears consistent with the available empirical evidence on household economies of scale. ${ }^{8}$

The presence of children alters our problem for two reason. First, as mentioned, it changes the relationship between consumption expenditures and living standard. Second, it affects insurance requirements for each spouse not only when both are alive, but also when each is the lone survivor. Surviving spouses need life insurance to ensure that children, if orphaned, would have sufficient resources to maintain the household's target living standard through age 18. In evaluating life insurance needs when both spouses are alive, we account for the fact that a surviving spouse's off-the-top expenses would include premium payments for the

\footnotetext{
${ }^{7}$ Our child-adult equivalency factor is that used by the OECD (see Ringen, 1991). Nelson's (1992) work suggests a smaller value, but she considers total household expenditures whereas our child-adult equivalency factor applies only to non-housing consumption expenditure; i.e., ESPlanner treats housing expenditure as "off-the-top." It appears from Nelson's work that a higher equivalency factor is appropriate for non housing expenditures.

${ }^{8}$ The OECD uses a value of .7 for $\alpha$ (see Ringen, 1991). Williams, et. al. (1998) consider values of .5 for both $\alpha$ and $\beta$.
} 
aforementioned life insurance coverage.

\section{Special expenditures}

Over the course of their lives, individuals incur a variety of substantial, non-recurring expenses. Examples include college tuition, wedding expenses, and funeral costs. In our view, it would be inappropriate to assume that individuals wish to smooth a measure of aggregate consumption that includes these nonrecurring items. Consequently, the software treats them as "off-the-top" fixed expenses. In other words, for each year, we subtract projected special expenses from income, and then compute the household's highest sustainable standard of living, defined by the level of ordinary recurring expenses.

\section{Housing}

In principle, economic theory suggests that it is appropriate to lump housing services in with other consumption expenditures. In practice, there are two complications. First, the stream of housing expenditures (such as mortgage payments) does not correspond, even approximately, to the stream of housing services. To see this point, note that mortgage payments decline in real terms as a result of inflation and end at some specified point in time, even though the homeowner continues to receive a relatively steady stream of real housing services. Second, housing is a lumpy, sticky decision. Moving entails significant economic and psychological costs. Consequently, barring extreme changes in their economic situations, most households strongly prefer to remain in their existing home. Indeed, in the HRS sample, 5,933 respondents reported that they planned to retain their current home after retirement, while only 2,233 indicated that they expected to move (or had already moved) for retirement. ${ }^{9}$

${ }^{9}$ More specifically, 5,753 said that they planned to stay in their current home after retirement, 180 said that the expected to divide time between their current home and another location, 2,192 said that they planned to move, 41 said that they had already moved, and 679 said that they don't know. In addition, 3,705 households were not asked the question (mainly because they had already retired), and 102 households were asked but did not answer. 
In light of these considerations, we believe that it is most appropriate to assume that individuals will remain in their current houses, and to treat their housing expenditures similarly to special expenditures, subtracting them from income "off-the-top." Housing expenditures consist of payments for mortgages, rent, condo fees, maintenance, homeowners insurance, and property taxes. In effect, we solve for the highest sustainable standard of living based on non-housing expenditure, fixing expenditures associated with the household's current housing choice.

\section{Social Security Benefits}

The financial planning software used for this study contains a highly detailed Social Security benefit calculator. Since we have access to administrative records on covered earnings, this allows us to account fully and accurately for eligibility rules, early retirement reductions, delayed retirement credits, benefit recomputation, the legislated phased increase in the normal retirement age, the earnings test, restrictions on maximum family benefits, the wage indexation of average indexed monthly earnings, and the price indexation of benefits once they are received. Each of these elements feeds into the calculation of Social Security retirement benefits (both for the eligible individuals and for his or her spouse), as well as survivor benefits for widows, widowers, and children. The availability of these survivor benefits plays an important role in determining life insurance needs. Notably, in solving the life cycle planning problem, we account for the fact that benefits paid to survivors in any future year depend on the timing of the covered individual's death.

\section{Income and Payroll Taxes}

The financial planning software used for this study calculates federal and state income and payroll taxes. The income tax calculations are highly detailed. In the case of the federal income tax, for each year and state of nature, the software computes itemizable deductions, and determines whether the household should itemize or take the federal standard deduction. For the purposes of the current study, itemizable deductions 
include state income taxes, mortgage expenses, and property taxes. The software incorporates federal deductions and exemptions, specific rules concerning the taxation of social security benefits, the earned income tax credit, the child tax credit, the phase out at higher income levels of itemized deductions, and the indexation of tax brackets to the consumer price index. The software permits the deduction from taxable income of contributions to tax-favored accounts, and includes in taxable income withdrawals from these accounts.

\section{Tax-deferred retirement savings accounts}

Tax deferred retirement savings accounts, such as Individual Retirement Accounts (IRAs) and 401(k)s, provide households with opportunities to earn higher effective after-tax rates of return, but only by sacrificing liquidity. Without knowing much more about risks and preferences, it is therefore impossible to determine the optimal division of saving between tax-deferred retirement accounts and other assets. Rather than impose additional structure on the optimization problem, the software treats contributions to tax-deferred accounts as exogenous, and calculates the incremental conventional saving and life insurance holdings required to achieve the highest living standard that is sustainable in light of these fixed contributions.

\section{What's Left Out}

Although the software used in this project considers many key factors that enter into saving and insurance decisions, it does not consider all relevant factors. Consequently, we do not view it as providing a perfect measure of the amount of life insurance required to assure a stable living standard. However, we do think that it provides a reasonable benchmark against which to measure financial vulnerabilities.

Two specific omissions merit discussion. First, the software does not take into account the uncertainty of future income or expenditures on necessities, such as non-insured health care costs. This probably leads us to understate the significance of financial vulnerabilities (see, e.g., Kotlikoff, 1989). Second, the software does not account for possible changes in marital status, such as remarriage after a spouse's death. To some 
extent, the remarriage option may mitigate financial vulnerabilities associated with the risk of a spouse's death. There are, nevertheless, legitimate reasons to ignore this possibility. Arguably, the choice of whether to remarry should not be dictated by financial necessity. In addition, the economic well-being of a remarried individual may be determined by his or her financial status prior to remarriage, insofar as this affects bargaining power within the new marriage (see e.g. Lundberg, 1999). In any case, remarriage after a spouse's death is less common among the group of individuals studied here -- those approaching retirement -- than among younger individuals.

\section{Some examples}

Table 1 presents several examples of the program's calculations. ${ }^{10}$ These calculations all reflect variations on the following base case. A 54 year old man earning $\$ 45,000$ per year is married to a 50 year old woman earning $\$ 25,000$ per year. The man intends to retire at age 64 , the woman at age 63 . They have one 18 year old child. The net value of their non-housing assets is $\$ 50,000$; in addition, they own a $\$ 100,000$ home against which they have a $\$ 20,000$ debt. They expect their real earnings to grow at the rate of one percent per year until retirement. They also expect to earn a real after-tax return of 3 percent on their non-housing investments. Our calculations indicate that, to maintain a stable standard of living, this couple should hold $\$ 133,500$ in term life insurance (roughly three times earnings) to protect the husband's earnings, and no term life insurance to protect the wife's earnings.

The rest of Table 1 illustrates the effects of changing specific characteristics. If the spouses were four years older, recommended insurance on the husband's life would fall to $\$ 68,500$, or roughly 1.5 years worth of earnings, reflecting the associated reduction in cumulative future earnings potential. Conversely, if the spouses were four years younger, recommended insurance on the husband's life would rise to $\$ 192,000$, or

\footnotetext{
${ }^{10}$ For additional examples, see Gokhale, Kotlikoff, and Warshawsky (1999).
} 
just over four times earnings.

Recommended insurance rises monotonically and more than proportionately with husband's earnings. Specifically, the insurance/earnings ratio is 2.35 when the husband earns $\$ 30,000,2.97$ when the husband earns $\$ 45,000$, and 3.25 when the husband earns $\$ 60,000$. This pattern reflects the diminishing relative magnitude of the wife's earnings and Social Security benefits. Note also that when the husband earns only $\$ 30,000$, the program indicates that it is appropriate to purchase term insurance on the wife exceeding a year's worth of her earnings.

An increase in the wife's earnings from $\$ 25,000$ to $\$ 40,000$ reduces the recommended insurance level of the husband's life by $\$ 22,000$, and results in a recommendation that the couple should hold $\$ 69,000$ worth of insurance on the wife's life. Conversely, a reduction in the wife's earnings to $\$ 10,000$ raises the recommended level of insurance on the husband's life by just over $\$ 40,000$. Note that these effects are asymmetric: the absolute value of the change in recommended insurance on the husband's life is smaller when the wife's earnings are increased by $\$ 15,000$ than when the wife's earnings are decreased by this amount.

The presence of dependent children also has an impact on prescribed insurance levels. The addition of a second, 16 year-old child raises recommended insurance on the husband's life by just over $\$ 5,000$. Conversely, the removal of the 18 year-old child reduces recommended insurance on the husband's life by $\$ 1,500$. These amounts are small because the children are nearly adults. Much larger effects would be observed for the addition or subtraction of younger children.

Insurance recommendations are moderately sensitive to assumptions about earnings growth and rates of return. Higher earnings growth should be associated with higher insurance, since there is more human capital to protect. Higher rates of return should be associated with lower insurance, since they lead to a larger stream of income from assets that is not contingent on the survival of either spouse. However, a one percentage point increase or decrease in the earnings growth rate changes the recommended insurance level by less than 7.5 percent. Naturally, this effect would be larger for a younger couple. A two percentage point 
increase or decrease in the real after-tax rate of return changes the recommended insurance level by less than 14 percent.

Assessing Insurance Adequacy

To determine the adequacy of life insurance holdings, we compare actual insurance holdings in the period of observation, $\mathrm{L}_{\mathrm{h}}{ }^{\mathrm{a}}$ and $\mathrm{L}_{\mathrm{w}}^{\mathrm{a}}$, with prescribed insurance choices, $\mathrm{L}_{\mathrm{h}}{ }^{*}$ and $\mathrm{L}_{\mathrm{w}}{ }^{*}$ (where $\mathrm{h}$ denotes the husband, and w denotes the wife). While comparisons between prescribed and actual levels of life insurance are useful, they are somewhat difficult to interpret in concrete terms. Ideally, we would like to know the consequences of low insurance, in terms of implications for living standards. We address this issue as follows.

Let $\mathrm{C}_{\mathrm{w}}^{\mathrm{a}}$ denote the level of consumption associated with the highest living standard that the wife could sustain if her husband died immediately (in year 0 ), given actual levels of life insurance held in that year. Analogously, define $\mathrm{C}_{\mathrm{h}}{ }^{\mathrm{a}}$ as the level of consumption associated with the highest living standard that the husband could sustain if his wife died immediately (in year 0 ), given actual levels of life insurance held in that year. We summarize the impact of underinsurance by computing $\left(\frac{C_{i}{ }^{a}}{C^{*}}-1\right) \times 100, i=w, h$. In Section 4, we refer to this variable as IMPACT. When the actual level of insurance is just right, IMPACT equals zero. When insurance is too low, IMPACT is less than zero, and it measures the extent (percentage) to which a survivor's living standard would be lower due to underinsurance. When insurance is too high, IMPACT is greater than zero, and it measures the extent (percentage) to which a survivor's living standard would be higher due to overinsurance.

\section{Data}

The data used in this study are drawn from the 1992 wave of the Health and Retirement Survey (HRS), 
which collected extensive data on 12,652 individual respondents. More specifically, the HRS sampled 5,000 married couples in which both spouses responded, 200 married couples in which one of the two respondents refused to answer, and 2,452 single individuals. Since a primary purpose of the HRS is to collect data on transitions into retirement, respondents are, on average, older than the general population. Indeed, the sample is representative of individuals in the 51-61 age range.

The survey provides information on health, income, wealth, pensions, social security benefits, demographics, education, housing, food consumption, family structure and transfers, current and past employment, retirement plans, cognition, health and life insurance, intra vivos gifts, inheritances, and bequests. ${ }^{11}$ Unfortunately, the HRS data fields do not match up perfectly with the inputs required by the financial planning software package used in this study. However, in most cases, it is possible to impute reasonable values for the program's inputs based on data that is available in the HRS. We used the following procedures to make these imputations:

\section{Life Insurance}

The HRS collects information about both term and "whole" (or "straight") life insurance policies. It does not, however, solicit the term component for the latter class of policies. For our purposes, it is essential to impute the term component (which is true life insurance) and the cash component (which is simply an asset). To do this, we make an imputation based on the relative magnitudes of term and cash components using information contained in the 1995 Survey of Consumer Finances (SCF). Specifically, using the SCF data, we regress the ratio of cash value to face value for all policies held by the couple on the age of each spouse, the face value of the policy, family income, family size, and financial assets; we then construct fitted values using data from the HRS. Notably, with regard to term insurance and the term component of whole life insurance,

\footnotetext{
${ }^{11}$ Mitchell and Moore (1997a and 1997b) provide excellent descriptions of the HRS, in general, and the wealth accumulation of the HRS sample in particular.
} 
we restrict attention to policies that name the spouse or children living in the household as beneficiaries. Roughly 5 percent of individuals hold a life insurance policy that names some other party or entity (such as a trust) as beneficiary.

\section{Non-Asset Income}

For each observation, the program requires us to specify each spouse's past and future covered earnings, as well as future total (covered and uncovered) earnings. We obtain past covered earnings from the HRS restricted data file. We impute future covered and total earnings as follows. First, we adjust actual earnings in the current year (1991) to remove the effects of temporary fluctuations, as follows. We assume that actual earnings for 1991 equal the maximum of 1991 reported earnings and 1991 covered earnings. We then define adjusted covered earnings in year $t \leq 1991$ as covered earnings in year $t$ adjusted for inflation to 1991 dollars times $(1+\text { assumed earnings growth rate })^{(1991-t)}$. Next, we define normal adjusted covered earnings as a five year average (1987-1991) of adjusted covered earnings. We then set normal earnings equal to 1991 earnings times the ratio of normal adjusted covered earnings to 1991 covered earnings.

To compute future earnings, we allow normal earnings to grow at the assumed real earnings growth rate. We obtain future covered earnings directly from imputed future earnings, based on applicable statutes. For our base case calculations, we assume that real earnings grow at the rate of one percent per year. We also present alternative calculations based on assumed earnings growth rates of zero percent and two percent.

The HRS also provides information on other kinds of non-asset income. We treat some of these, such as Veteran's Benefits, SSI, disability income, welfare, child support, and regular help from friends or relatives as non-taxable. We assume that these income streams continue, with full adjustments for inflation, until the respondent's death, except for Social Security disability income and child support payments. In making this assumption, we intend to overstate the magnitude of future resources, and thereby provide a conservative estimate of life insurance needs. Social Security disability income converts to a retirement benefit at age 62 . 
We divide any child support received by the number of children to obtain child support per child, which we assume is received until the child in question reaches $18 .^{12}$ We treat other kinds of special receipts, such as income from trust funds and royalties, as taxable. We assume that they will be received for ten years beyond the survey date, and that the payments will be constant in nominal terms. It is worth mentioning that relatively few respondents receive these kinds of income flows, and the amounts are generally small relative to average earnings.

\section{Retirement}

The HRS asks respondents to indicate their intended ages of retirement. Generally, we assume that individuals follow through on these plans; however, we truncate the intended retirement age at 70 . For those who fail to answer this question, we assume that retirement will take place at age 65 .

Pension Plans, Retirement Accounts, and Social Security

The HRS provides information on nominal benefits currently received from defined benefit pension plans as well as expected nominal benefits for future pension recipients. It also indicates whether these benefits are indexed for inflation. We assume that a surviving spouse would receive 100 percent of the monthly benefit or lump-sum distribution. We further assume that employer-sponsored defined contribution plans and all private retirement accounts (IRAs and Keoghs) provide for tax-deductible contributions and taxdeferred accumulation. Contributions in all future years up to age 59 are set equal, in real terms, to contributions in the survey year. The HRS contains information on 401(k) accounts for individual spouses, but IRA and Keogh account balances are reported only at the household level. We impute each spouse's IRA

\footnotetext{
${ }^{12}$ The HRS reports only the sum of child support and spousal support. However, we confine our attention to couples, 98 percent of which are married. Since spousal support generally ends upon remarriage (and also declines somewhat on average when individuals become unmarried partners), we can safely assume that the entire reported amount is child support.
} 
and Keogh account balances and contribution amounts based on their share of 1991 household labor earnings. ${ }^{13}$

We code an individual as having a pension or retirement account of a particular type if and only if the individual affirmatively indicated that they had such a pension or retirement account. If the individual provided insufficient information to ascertain whether he or she has a pension or retirement account (for example, if the response was "don't know"), we assume that no such account existed.

The financial planning software used in this study requires us to specify the age at which an individual will begin receiving social security benefits. If an individual is already receiving benefits, we assume that benefits have already started. Otherwise, we impute the initial age of benefit receipt as follows. If the individual is still working, we assume that benefits will start at his or her projected retirement age (but not earlier than age 62). If the individual is retired, we assume that benefits will start at age 62 for those currently under 62 , and at the current age for those over 62 . In all cases, the initial age of benefit receipt is between 62 and 70 . For respondents currently receiving social security disability benefits, we assume that they switch to retirement benefits at age 62 .

The program also requires information on the age at which individuals begin to receive private pension benefits. If the individual is already receiving benefits, we assume that benefits have already started. If the individual is not receiving benefits, but indicates the age at which he or she expects benefits to begin, we use that age. Otherwise, we impute the initial age of pension benefit receipt in exactly the same manner as for Social Security retirement benefits, based on work status, current age, and projected retirement age. In all cases, we truncate the benefit inception date at 70 .

Individuals with previous marriages lasting more than ten years and ending in divorce or separation

\footnotetext{
${ }^{13}$ Which spouse owns these balances influences the timing of withdraws. This, in turns, affects their taxation. The timing of withdraws also may influence whether or not the couple is liquidity constrained as it approaches retirement.
} 
(roughly 20 percent of the total HRS sample), and individuals with previous marriages lasting more than nine months and ending in the spouse's death (roughly 8 percent of the total HRS sample) are eligible to receive Social Security benefits based on the earnings history of their prior spouse. This presents us with a problem, since we have no access to covered earnings histories for prior spouses. We assume that all such individuals receive benefits based on either their own earnings history or that of their current spouse.

\section{Housing}

Our calculations require information on a variety of specific housing expenditures, including mortgages, home insurance premia, property taxes, and other recurring expenses. Fortunately, it is possible to construct reasonable estimates of these variables using the HRS data. The HRS contains detailed information on recurring expenses such as association fees and site rental charges for households living in mobile homes. While it does not contain information on home insurance premiums, it did collect the face amount of insurance. We imputed annual home insurance premia by assuming a rate of $\$ 0.0025$ for each dollar of insurance coverage. Information on property taxes is usually available. When it is not, we impute it using the home value and applying the average ratio of property taxes to home value obtained from the rest of the sample.

In some instances, mortgage payments reported in the sample include property taxes and home insurance premiums; in such cases, respondents were not asked separately about their taxes and premiums. We impute property taxes from home value by applying the average ratio of property tax to house value for our entire sample. Similarly, we impute insurance premia by applying the average ratio of (imputed) insurance premium to house value for our entire sample. We assume that the mortgage payment accounts for any residual.

Unfortunately, the HRS does not report the number of years left on each mortgage. We assume that each household took out a 30 year mortgage in the year it purchased its home (which is reported in the HRS), 
and that it has never refinanced; this allows us to compute the number of years remaining on the mortgage. In cases where the respondent did not report a mortgage payment, we impute one based on the reported balance, the imputed number of years left in the loan, and a representative mortgage interest rate for 1991.

In some instances, rental payments reported in the sample include heat and electricity expenses; in such cases, respondents were not asked separately about these utility payments. We apportion the reported number into separate components by assuming that the ratio of rent to utilities is the same for these respondents as the average ratio computed from the rest of the sample. The HRS does not include any information concerning property taxes paid on second homes. We calculate these from second home values based on the assumption that the ratio of property taxes to value is the same as the average for primary homes $(0.0018$ monthly). Finally, we set monthly rental payments equal to zero for the few respondents who report that they live in a house or apartment that they neither rent nor own.

\section{Other Variables}

For confidentiality reasons, the HRS does not report the respondent's date of birth or state of residency. We assume that each respondent is born on the fifteenth of his or her birth month. ${ }^{14}$ For the purposes of computing state taxes, we use Massachusetts law. We set the maximum age of life to 95 for all individuals. We assume that funeral expenses and associated legal fees for deceased spouses will be equal (in real terms) to the sample median for those who died in 1991 ( $\$ 5,000$, based on 90 observations). Aside from funerals, we do not impute any other special expenditures. We set intended bequests equal to zero. As a measure of a household's net worth, we use total non-housing assets minus total non-housing liabilities. Total non-housing assets include checking and saving accounts, money market funds, CDS, government saving bonds, T-bills, stocks, mutual funds, investment trusts, business equity, bonds, bond funds, real estate other than primary and vacation homes, the cash value of life insurance policies, and some miscellaneous items.

\footnotetext{
${ }^{14}$ Ten respondents did not report month of birth; we assume they were born in June.
} 
Total non-housing liabilities include personal loans, student loans, credit card balances, car loans, installment loans, and other non housing debt. Housing equity and debt (mortgages and equity lines of credit) are accounted for in the housing portion of the software. We assume that, apart from mortgages and other outstanding housing debt, households cannot borrow more than $\$ 50,000$. We assume a 3 percent rate of inflation and three possible before-tax real interest rates for non tax-favored as well as tax-favored investments. These rates are 1 percent, 3 percent (our base-case assumption), and 5 percent.

\section{Sample Selection}

The sample used in our analysis consists of 2,261 couples. We excluded couples if any of the following statements were true: a) Social Security earnings records were not available for at least one spouse; b) the couple failed to specify the face value of any life insurance policy; c) the couple didn't respond when asked if they had life insurance policies; d) one spouse refused to be interviewed; e) at least one spouse was unemployed; or f) the couple's reported income and other economic resources were insufficient to support its reported "off-the-top" expenditures. The first criterion (availability of administrative records for both spouses) accounted for the vast majority (nearly 80 percent) of excluded observations. The second criteria (availability of data on the face value of life insurance policies) accounted for most of the remaining exclusions.

\section{Summary Statistics}

Table 2 provides some descriptive statistics for our final sample. The top half of the table provides information on the household, while the lower half of the table provides information separately on husbands, wives, primary earners, and secondary earners. Notice that the typical individual in the sample is in his or her mid-50s. Consequently, these households have relatively few dependent children (roughly one for every four households). The median value of non-housing net wealth is $\$ 36,500$, but the wealth distribution is highly skewed, so that the mean is more than four times as large (near $\$ 160,000$ ). Approximately 90 percent of these 
couples own their own homes, and the typical home value is in the neighborhood of $\$ 100,000$. Median and mean household non-asset incomes are $\$ 47,500$ and $\$ 62,500$, respectively. Roughly 82 percent of the sample is white. More than one quarter of husbands and just under one fifth of wives are college educated. A total of 42 percent of husbands and 33 percent of wives are covered by private pension plans. On average, husbands account for roughly three-quarters of a household's non-asset income, but wives are primary earners in about one fifth of households.

\section{Results}

Table 2's comparison of the population means and medians for actual and recommended life insurance reveals a pattern of systematic underinsurance. First, consider the left-hand panel, which reports amounts for husbands and wives separately. The mean level of recommended life insurance for husbands $(\$ 88,000)$ is roughly 50 percent higher than the mean level of actual insurance $(\$ 60,000)$. Medians are lower $(\$ 31,000$ and $\$ 20,000$, respectively), but the percentage difference is roughly the same. The mean level of recommended life insurance for wives $(\$ 28,000)$ is also roughly 50 percent higher than the mean level of actual insurance $(\$ 19,500)$. Medians are again lower $(\$ 11,000$ and $\$ 3,000$ respectively), but the absolute difference $(\$ 8,000)$ is roughly the same as for the means.

Next, consider the right-hand panel of Table 2, which reports amounts for primary and secondary earners, including non-earners. There we see that primary earners tend to have too little insurance, while secondary earners tend to be have too much insurance. The mean level of recommended insurance for primary earners $(\$ 101,500)$ is nearly 75 percent larger than the mean level of actual insurance $(\$ 58,400)$. The ratio of medians for recommended and actual insurance on primary earners ( $\$ 41,000$ and $\$ 20,000$ respectively) is more than two to one. Conversely, the mean level of actual insurance $(\$ 21,000)$ exceeds the mean level of recommended insurance $(\$ 14,500)$ for secondary earners. The same relationship holds for medians $(\$ 3,500$ vs. \$0). 
As discussed in Section 2, comparisons between recommended and actual levels of life insurance are somewhat difficult to interpret in concrete terms. Ideally, we would like to know the consequences of low insurance, in terms of implications for living standards. We address this issue by calculating the variable IMPACT for each spouse. To review, when insurance is appropriate, IMPACT equals zero. When insurance is too low, IMPACT is less than zero, and it measures the extent (percentage) to which a survivor's living standard would be lower due to underinsurance. When insurance is too high, IMPACT is greater than zero, and it measures the extent (percentage) to which a survivor's living standard would be higher due to overinsurance.

The final line of Table 2 provides means and medians for the variable IMPACT. These numbers suggest that underinsurance is a significant problem for a sizable segments of the population, especially women and secondary earners (including non-earners). For husbands, the mean and median of IMPACT are $-3.50 \%$ and $0 \%$, respectively. Thus, the median husband is properly insured -- probably a reflection of the fact that recommended and actual insurance are both zero for many husbands. The discrepancy between the mean and the median reflects the leftward skewness of the variable's distribution, and suggests that a significant minority of husbands may be inadequately protected by insurance on their spouses. Not surprisingly, the figures for primary earners suggest even less vulnerability (mean of $-0.81 \%$, median of $0 \%$ ). Married women (mean of $-8.80 \%$, median of $-1.50 \%$ ) and secondary earners (mean of $-11.50 \%$, median of $-4.50 \%$ ) exhibit far greater vulnerability. Moreover, the leftward skewness of these distributions (indicated by the discrepancies between the means and medians) points to substantial insurance shortfalls among large groups of women and secondary earners.

Clearly, to learn more about the financial vulnerabilities implied by the statistics summarized in the last few lines of Table 2, one must study the distribution of the variable IMPACT in greater detail. We summarize these distributions in tabular form and through quantile regressions. 


\section{A. The Anatomy of the Underinsured -- Tabular results}

Tables 3 through 9 slice the distribution of IMPACT in a variety of ways. Each table reports the distribution of IMPACT across seven ranges $(<-40 \%,-40 \%$ to $-20 \%,-20 \%$ to $0 \%, 0 \%, 0 \%$ to $+20 \%,+20 \%$ to $+40 \%$, and $>+40 \%$ ) for the indicated population segments. Note that $0 \%$ is a separate category. Contrary to appearances, this is not a knife-edge case. Since insurance purchases much be non-negative, recommended life insurance is zero for a sizable number of individuals. Moreover, many of these same individuals have no life insurance, which implies that IMPACT $=0$. Thus, a significant number of observations fall into the $0 \%$ category. Henceforth, we will refer to individuals with IMPACT $<0$ as "underinsured," to individuals with $-40 \%<$ IMPACT $<-20 \%$ as "significantly underinsured," and to individuals with IMPACT $<-40 \%$ as "severely underinsured." Each table also reports statistics separately for husbands, wives, primary earners, and secondary earners. Note carefully how these term "underinsured" is used here. When we say that a husband is underinsured, we mean that the husband is inadequately protected, which occurs when there is too little life insurance on the wife's life.

Table 3 describes the distribution of IMPACT for the entire population. Roughly one-quarter of husbands (24.37 percent) are underinsured, but the degree of underinsurance is small. Only 11.63 percent of husbands are significantly or severely underinsured, and only 5.57 percent are severely underinsured. Underinsurance is much more common among wives ( 51.13 percent), and the degree of underinsurance is much more pronounced. Nearly 30 percent of wives are significantly or severely underinsured, and nearly 15 percent are severely underinsured.

Naturally, since some wives are primary earners, the discrepancy in the adequacy of insurance coverage between primary and secondary earners is more pronounced than that between husbands and wives. Only one-fifth (20.87 percent) of primary earners are underinsured, versus 54.63 percent of secondary earners. Only one in thirteen primary earners ( 7.65 percent) are significantly or severely underinsured, compared with roughly one secondary earner in three (33.78 percent). Likewise, only one in thirty-four ( 2.96 percent) primary 
earners are severely underinsured, compared with just over one in six (17.34) secondary earners.

Table 4 depicts the distribution of IMPACT by household income. Generally, there is a tendency for the frequency of underinsurance to fall with income at low levels of income, and then to level off at moderate level of income. In households with earnings under $\$ 45,000,29.25$ percent of husbands and 56.19 percent of wives are underinsured, compared with 20.06 percent of husbands and 48.13 percent of wives in households with earnings between $\$ 45,000$ and $\$ 100,000$, and 21.60 percent of husbands and 41.21 percent of wives in households with earnings over $\$ 100,000$. In households with earnings under $\$ 45,000,25.41$ percent of primary earners and 60.02 percent of secondary earners are underinsured, compared with 17.88 percent of primary earners and 50.30 percent of secondary earners in households with earnings between $\$ 45,000$ and $\$ 100,000$, and 13.07 percent of primary earners and 49.76 percent of secondary earners in households with earnings over $\$ 100,000$.

The patterns are somewhat different for significant and severe underinsurance. Generally, there is a tendency for the frequency of significant and severe underinsurance to fall with income at low levels of income, and to rise with income at high levels of income. For example, in households with earnings below $\$ 45,000,17.26$ percent of wives are severely underinsured, compared with 11.76 percent of wives in households with earnings between $\$ 45,000$ and $\$ 100,000$, and 17.09 percent of wives in households with earnings over $\$ 100,000$. Notably, in households with incomes over $\$ 100,000$, more than one in four $(25.63$ percent) of secondary earners are severely underinsured. Significant and severe underinsurance among secondary earners may be more common among high income households because these households are more likely to have a single high earner, and because Social Security survivor benefits replace a much smaller fraction of income.

Table 5 provides separate results for single earner and dual earner families. Note that, as one would expect, cases of underinsurance (significant, severe, and overall) are much less common among husbands and 
primary earners in single earner families than in dual earner families. ${ }^{15}$ Conversely, severe underinsurance is more common among wives and secondary earners in single earner families than in dual earner families. Though the opposite pattern holds for significant underinsurance, the combined frequency of significant and severe underinsurance is higher among wives and secondary earners in single earner families than in dual earner families. Notably, more than one out of five (21.24 percent) non-earners in single earner households is severely underinsured, and roughly another one in seven (14.03 percent) is significantly underinsured. Surprisingly, however, the overall level of underinsurance is roughly the same for wives in single earner (52.91 percent) and dual earner (50.62 percent) households, and for secondary earners in single earner (54.11 percent) and dual earner (54.76 percent) households.

Table 6 provides separate results based on the spouses' relative incomes. For this purpose, we define relative income as either the ratio of husbands income to wife's income, or the ratio of the primary earner's income to the secondary earner's income. Several interesting patterns emerge from this table. First, the incidence of significant and severe underinsurance of wives and secondary earners increases with relative income. For example, when secondary earnings are at least half of primary earnings, only one secondary earner in ten ( 10.10 percent) is severely underinsured. In contrast, when secondary earnings are less than 25 percent of primary earnings, nearly one secondary earner in four ( 23.18 percent) is severely underinsured. The overall incidence of underinsurance for primary earners also varies with relative income, but to a lesser extent (51.96 percent when secondary earnings are at least half of primary earnings, and 55.57 percent when secondary earnings are less than 25 percent of primary earnings).

A second interesting pattern in Table 6 emerges when one compares the adequacy of insurance for secondary-earner husbands (with relative income less than one) and secondary-earner wives (with relative income greater than one). More than one in five (20.58 percent) secondary earner husband is severely

\footnotetext{
${ }^{15}$ Since some non-earners have significant life-contingent income streams (such as disability payments), a small fraction of primary earners are underinsured even in single-earner households.
} 
underinsured, 37.29 percent are either significantly or severely underinsured, and 57.87 percent are underinsured. The corresponding figures are lower for secondary-earner wives, even when the wife's earnings do not exceed 25 percent of the husband's earnings. Thus, under symmetric conditions, households are more likely to underinsure husbands than wives. One must, however, exercise caution when interpreting this finding. Secondary-earner husbands may require less insurance either because their low-earner status is temporary, or because they are more likely to obtain greater earnings if widowed. Due to data limitations, recommended insurance levels do not account for either of these possibilities.

Table 7 depicts the distribution of IMPACT by the age of the individual in question. Age is a critical determinant of insurance needs, since younger households have more future earnings to protect. The results in table 7 indicate that households do not adjust their life insurance holdings adequately to compensate for these needs, and that, as a result, underinsurance is both more common and more extreme among younger individuals. In particular, among 40-something individuals, 65.18 percent of wives and 71.02 percent of secondary earners are underinsured, 42.71 percent of wives and nearly half ( 48.70 percent) of secondary earners are either significantly or severely underinsured, and 20.49 percent of wives and 22.90 percent of secondary earners are severely underinsured. The figures are much lower at more advanced ages. For example, among 60-something individuals, 32.66 percent of wives and 36.59 percent of secondary earners are underinsured, 14.58 percent of wives and 18.05 percent of secondary earners are either significantly or severely underinsured, and 4.96 percent of wives and 8.05 percent of secondary earners are severely underinsured. Generally, husbands and primary earners are less vulnerable to the death of a spouse than are wives and secondary earners, but the qualitative relationship between vulnerability and age is similar.

In principle, households can use life insurance to protect children as well as surviving spouses. However, the results in Table 8 suggest that households do not adjust their life insurance holdings adequately to compensate for the additional financial needs that arise when children are present in the household. When no children are present, 51.81 percent of secondary earners are underinsured, 31.03 percent are significantly 
or severely underinsured, and 15.78 percent are severely underinsured. When children are present, 68.60 percent of secondary earners are underinsured, 47.23 percent are significantly or severely underinsured, and more than one in four (25.07 percent) are severely underinsured. Results for wives are similar. Once again, the husbands and primary earners are less vulnerable to the death of a spouse than are wives and secondary earners, but the qualitative relationship between vulnerability and children is similar.

Table 9 explores the relationship between insurance adequacy and ethnicity. The results in this table indicate that non-whites are much more likely to be underinsured than whites. To some extent, this may reflect differences in life expectancy; we return to this issue in the next subsection. Comparing non-whites to whites, the frequency of severe underinsurance is more than three times as high among husbands (4.12 percent vs. 12.56 percent), nearly twice as high for wives ( 24.28 percent vs. 12.78 percent), roughly five times as high for primary earners ( 9.23 percent vs. 1.66 percent), and nearly twice as high for secondary earner (27.68 percent vs. 15.23 percent). Notably, among non-white households, more than one secondary earner in four is severely underinsured (27.68 percent), and nearly half (49.35 percent) are significantly or severely underinsured. For non-whites, notable vulnerabilities are reasonably common even among primary earners $(9.23$ percent severely underinsured, and 18.46 percent either significantly or severely underinsured).

Tables 10 and 11 illustrate the sensitivity of our basic results (those contained in Table 3 ) to different assumption about the real interest rate (Table 10) and the rate of real wage growth (Table 11). Our results clearly depend on the interest rate assumption, but to a smaller extent than one might imagine. Recall that our base case assumes a real interest rate of 3 percent and a real wage growth rate of 1 percent. According to Table 10 , varying the real interest rate from 1 percent to 5 percent has the following effects for secondary earners (qualitatively similar results hold for husbands, wives, and primary earners): the frequency of severe underinsurance rises from 15.24 percent to 19.06 percent, the frequency of significant or severe underinsurance rises from 32.57 percent to 33.57 percent, and the frequency of underinsurance falls from 56.82 percent to 51.88 percent. According to Table 11, varying the rate of growth for the real wage rate from 0 percent to 2 
percent has the following effects for secondary earners (again, we find qualitatively similar results for husbands, wives, and primary earners): the frequency of severe underinsurance rises from 15.71 percent to 17.51 percent, the frequency of significant or severe underinsurance rises from 31.16 percent to 33.92 percent, and the frequency of underinsurance rises from 52.45 percent to 54.71 percent. Thus, our central findings appear to be robust with respect to plausible changes in the assumed values of key parameters.

\section{B. The Anatomy of Underinsurance -- Quantile Regression Results}

In discussing Tables 4 through 9, we described the manner in which underinsurance varies with a number of socio-economic variables. In these simple tabulations, a change in one socio-economic characteristic is often correlated with changes in other characteristics. For example, in the HRS sample, households with minor children are also likely to be younger. Does the greater insurance gap for households with children reflect the presence of children, or the age of the household?

To answer this question and others like it, we estimate a number of regression equations explaining the degree of underinsurance. Our dependent variable is IMPACT, and our independent variables include the following socio-economic characteristics: total earnings (non-asset income) for the couple, the ratio of the spouse's earnings to the couple's total earnings, the ratio of household net worth to the couple's total earnings, age (self and spouse), the number of dependent children, ethnicity (of household head), a dummy variable indicating whether the household head completed college, a dummy variable indicating whether the individual is covered by an employee pension (self and spouse), a dummy variable indicated whether the couple own their home, and the self-assessed probability that the individual will reach age 75 (self and spouse).

It is important to emphasize that the degree of underinsurance is not well-summarized by the mean value of IMPACT. A significant fraction of the population could be at significant or severe risk even if the average value of IMPACT was zero or positive. Hence, OLS regression is an inappropriate tool for our purposes. In order to shed light on the manner in which the distribution of IMPACT varies with socio- 
economic characteristics, we estimate quantile regressions for the 25 th, 50 th (median), and 75 th percentiles. As in Tables 3 through 11, we present separate results for wives and husbands (Table 12), as well as for primary and secondary earners (Table 13).

The total earnings (non-asset income) of the couple does not enter any of the specifications with a statistically significant coefficient. This is not particularly surprising in light of Table 4, which exhibited a relatively weak relation between income and insurance adequacy. Some of the patterns in Table 4 suggest that this relation might be non-linear. However, when we add the income-squared to these specifications (not included), none of the coefficients for the linear or quadratic terms are statistically significant. Consequently, controlling for other characteristics, the incidence and severity of underinsurance is largely unrelated to income.

Our regressions generally indicate that the adequacy of insurance declines when the spouse receives a larger fraction of the couple's earnings. Insurance needs plainly rise with the spouse's earnings share; apparently, households to not compensate adequately for these incremental needs. Note that the effect is more pronounced for wives and secondary earners than for men and primary earners. Note also that the effect is strongest among those who are least well insured (that is, at the 25 th percentile of the conditional distribution of IMPACT). Indeed, at the top end of the distribution (the 75th percentile), the effect vanishes for all groups (wives, husbands, primary earners, and secondary earners) ${ }^{16}$ This suggests that the population is divided between individuals who are deliberate about their life insurance purchases, and those who are not. Deliberate individuals insure adequately and adjust their insurance on the margin to compensate for characteristics that create greater insurance needs. Those who are not deliberate insure inadequately and fail to adjust insurance on the margin to compensate for incremental vulnerabilities.

We find no evidence to indicate that the adequacy of insurance varies significantly with household net wealth (which we measure relative to income). This is somewhat surprising, since assets provide a potential

\footnotetext{
${ }^{16}$ For husbands and primary earners, there also appears to be no significant effect at the median.
} 
substitute for life insurance. We believe that this finding is probably attributable to several facts: first, wealth is measured with a great deal of noise; second, for most couples, housing is by far the most important asset; third, the regression controls separately for home ownership. Consequently, the true wealth effect may manifest itself through the coefficient of the home ownership variable.

In principle, age is another important determinant of insurance needs. All else equal, younger individuals have to spread their resources, including insurance proceeds, over a greater number of years, and hence their vulnerabilities are greater. Individuals with younger spouses are also more vulnerable, since the present value of future earnings is typically greater for younger workers. Our estimates for wives and secondary earners indicate that households do not compensate adequately for age-related needs. Younger wives (secondary earners) and wives (secondary earners) with younger husbands (spouses) are significantly less well insured. Note again that this pattern is strongest among those least well-insured (that is, at the 25 th percentile), and it becomes weaker as one moves up the population distribution. While age may also be a factor in determining insurance needs for husbands and primary earners, our estimates indicate that it is not a particularly important determinant of underinsurance for members of these groups. For husbands, there is some evidence that spouse's age has a noticeable effect on insurance adequacy at the lower end of the distribution of IMPACT (specifically, the effect is marginally significant at the 25 th percentile and significant at the median, but insignificant at the 75 th percentile).

Surprisingly, we find relatively little evidence that underinsurance becomes more acute with the number of dependents. The coefficients for this variable are significant only in the specifications describing the distribution of IMPACT for husbands. We suspect that the relative unimportance of dependents is attributable to the age of our sample. In most cases, dependent children of 50-something and 60-something households are in their teens, and have relatively few years remaining in the household.

The correlation between underinsurance and ethnicity noted in Table 9 comes through quite strongly in the regressions. Like some of the other effects discussed above, it is strongest among those who are least 
well insured (it tends to decline as one moves from the 25 th percentile to the median, and from the median to the 75 th percentile). It is also considerably stronger for wives and secondary earners than for husbands and primary earners.

The educational attainment of the household head emerges as an important determinant of insurance adequacy among wives and secondary earners, but not among husbands and primary earners. To some extent, education may proxy for potential earnings growth. If that is the case, then greater education of the household head (typically the husband or primary earner) would increase the insurance needs for the protection of the head's spouse (typically the wife or secondary earner), but not necessarily for the protection of the head. This would account for the fact that education has a significant effect on insurance adequacy for wives and secondary earners, but not for husbands or primary earners. However, this reasoning does not explain the direction of the estimated effect. If greater education implies greater insurance needs, and if households tend to compensate inadequately for variations in needs, then education should be negatively correlated with insurance adequacy, contrary to our findings. The positive correlation between education and insurance adequacy suggests that college educated individuals may be more careful, deliberate, and/or forward-looking with respect to their insurance purchases. However, if that explanation is correct, then the absence of an effect for husbands and primary earners is puzzling.

Pensions affect insurance needs in several ways. Having a pension is similar to having greater income; generally, it reduces the need to protect the eligible individual by purchasing life insurance on his or her spouse. Life insurance needs also tend to be lower when an individual's spouse has a pension. This is because joint survivorship is, by law, the default option for private pension plans. Consequently, we would expect to find that the adequacy of life insurance is positively correlated with pension eligibility, both for the individual in question and for his or her spouse. Our regressions weakly corroborate this view. Their is some evidence that life insurance is more adequate for wives and secondary earners who are themselves covered by pensions, but not particularly for those whose spouses are covered by pensions. The opposite is true for husbands and 
primary earners: these groups tend to be more adequately insured when their spouses are eligible for pensions, but not when they themselves are eligible.

Our regressions indicate that home ownership is strongly related to insurance adequacy. Like several of the other effects described above, this relationship is more pronounced among those who are least well insured; it declines from the 25 th percentile to the median, and (at least for wives and secondary earners) from the median to the 75 th percentile. It is also stronger for wives and secondary earners than for husbands and primary earners.

If individuals have private information about their own survival probabilities, then the analysis of the preceding section may overstate the frequency and severity of underinsurance. An individual's spouse may carry little life insurance relative to our benchmark simply because the individual in question expects to die sooner than average, and therefore requires less protection. If this is the case, we should see a significant correlation between our measure of insurance adequacy (IMPACT) and self-assessed survival probabilities. In particular, the coefficient of an individual's self-assessed survival probability should be positive (indicating less apparent underinsurance for those who expect to die later, and more for those who expect to die earlier). However, there is no indication in either Table 12 or Table 13 that the adequacy of insurance, as we measure it, is systematically related to self-assessed survival probabilities for either the individual in question or for his or her spouse. ${ }^{17}$ Consequently, our findings concerning the scope of underinsurance cannot be attributed to differing beliefs about longevity.

One can also use the regression results in Tables 12 and 13 to compute fitted distributional statistics (values at the 25 th, 50 th, and 75 th percentiles) for population subgroups with particular combinations of characteristics. This is useful because it helps to measure the extent of the underinsurance problem for the

\footnotetext{
${ }^{17}$ To interpret the coefficients, it is important to understand that the HRS measures survival probabilities on a scale of 1 to 10. In other specifications (omitted), we also controlled for the self-assessed probability that the individual would survive until age 85 . Like the self-assessed probability of reaching age 75 , this variable never entered an estimated equation with a statistically significant coefficient.
} 
most vulnerable subgroups. Based on our discussion of tables 12 and 13, we would expect underinsurance to be most severe among young, non-working wives in households that rent their primary residence, and in which the household head is non-white and has not gone to college.

In Table 14 displays fitted distributional statistics for a "base case" and a "highly vulnerable case." For the base case, we assume that the household earns $\$ 50,000,75$ percent of which is attributable to the husband, assets equal $75 \%$ of annual income, the husband is 58 , the wife is 54 , there are no dependent children in the household, the household head is white and has not attended college, neither spouse has a pension, the couple owns a home, and each spouse believes that he or she has a 65 percent probability of reaching age 65 . These assumptions correspond roughly to sample medians. For the highly vulnerable case, we suppose that the spouse accounts for 100 percent of earnings ( 50 percent in the case of primary earners), the husband is 52 , the wife is 48 , there is one dependent child in the household, they are non-white, they rent their primary home, and in all other respects they are identical to the base case household.

For the base case group, 25 percent of wives would experience a decline in living standard of 21 percent or more. The median wife would experience a modest decline of 4.9 percent, and 25 percent of wives would experience increases in living standard of 6.9 percent of greater. These figures are similar for secondary earners (21.7 percent, 7.3 percent, and 3.7 percent, respectively).

Among the highly vulnerable group, the consequences of a spouse's death would be far more severe. One quarter of wives would experience a decline in living standard of 96.1 percent or greater. For secondary earners, the figure is in excess of 100 percent. This means that, at the 25 th percentile of the distribution for this group, the surviving secondary earner's resources would be insufficient to cover fixed "off-the-top" living expenses. Within the highly vulnerable group, the median decline in living standard would be a whopping 51.7 percent for wives (58.1 percent for secondary earners). Even at the 75 th percentile, standards of living would still decline significantly (12.9 percent for wives, 19.9 percent for secondary earners). Notice that the differences between the base case group and the highly vulnerable group are much more pronounced at the 
25 th percentile than at the median, and larger at the median than at the 75 th percentile. Thus, characteristics that are associated with underinsurance tend to create downward skewness in the distribution of the projected impact of a spouse's death.

Fitted values look very different for husbands and primary earners. Among the base case group, the entire interquartile range ( 25 th through 75 th percentile) is tightly concentrated around zero, ranging from -3.4 percent to +2.0 percent for husbands, and from -3.4 percent to +2.9 percent for primary earners. This is no doubt attributable in part to the fact that both actual and recommended insurance are either zero or near zero for a substantial fraction of these groups. Even among the highly vulnerable group, the median and 75th percentiles remain surprisingly close to zero (adequate insurance). However, there are substantial vulnerabilities for the bottom quarter of the highly vulnerable population. Within this group, living standards would decline by 60.1 percent or more for one-quarter of husbands, and by 32.2 percent or more for primary earners, upon the deaths of their spouses.

\section{Conclusions}

In this study, we have examined the adequacy of life insurance among U.S. households. We overcome the shortcomings of previous work on this subject in two ways. First, we use data that are both more recent and of higher quality (the 1992 wave of the Health and Retirement Survey, including matching files that provide information on Social Security earnings histories and pension characteristics). Second, we employ a new and highly detailed life-cycle financial planning software package to evaluate the life insurance needs of each household. In this way, we account for a much wider array of household characteristics, and more accurately control for the various factors that determine a household's insurance needs.

Our results point to widespread underinsurance. The impact of this underinsurance translates into a reduction in living standard of 20 percent or greater for more than 30 percent of surviving wives compared with only 11 percent of surviving husbands. Underinsurance tends to be more common among low income 
households (though we also document pockets of severe vulnerability among high income households), singleearner households (more generally, couples with asymmetric earnings), younger households, couples with dependent children, and non-whites. Thus, households with greater vulnerabilities do not appear to compensate adequately for these vulnerabilities through greater life insurance holdings. Among some groups, the frequency of underinsurance exceeds two-thirds, and the frequency of severe underinsurance (a reduction in living standard of 40 percent of greater) exceeds one-quarter. Through quantile regressions, we have identified more narrowly defined population subsegments for which vulnerabilities are even greater. 
Table 1: Sample life insurance recommendation

\begin{tabular}{lcc}
\hline \hline & $\begin{array}{c}\text { Insurance recommendations } \\
\text { for husband }\end{array}$ & $\begin{array}{c}\text { Insurance recommendations } \\
\text { for wife }\end{array}$ \\
\hline Base case & 133,500 & 0 \\
+ Age $(58,54)$ & 68,500 & 0 \\
- Age $(50,46)$ & 192,000 & 0 \\
+ Husband's earnings $(\$ 50,000)$ & 195,000 & 0 \\
- Husband's earnings $(\$ 20,000)$ & 70,500 & 28,000 \\
+ Wife's earnings $(\$ 30,000)$ & 111,500 & 69,000 \\
- Wife's earnings $(\$ 0)$ & 174,000 & 0 \\
+ Child (age 16) & 139,000 & 0 \\
- Child & 132,000 & 0 \\
+ Earnings growth $(2 \%)$ & 143,500 & 0 \\
- Earnings growth $(0 \%)$ & 125,000 & 0 \\
+ Real interest rate $(5 \%)$ & 118,500 & 0 \\
- Real interest rate $(1 \%)$ & 152,000 & 0 \\
\hline \hline
\end{tabular}

Assumptions for base case:

Age of husband: 54

Age of wife: 50

Husband's employee earnings: $\$ 45,000$

Wife's employee earnings: $\$ 25,000$

Husband's retirement age: 64

Wife's retirement age: 63

Number of children: 1

Age of child: 18

Non-housing net wealth: $\$ 50,000$

Primary home value: $\$ 100,000$

Mortgage balance: $\$ 20,000$

Earnings growth: $1 \%$

Real interest rate: $3 \%$ 
Table 2: Descriptive statistics

Table 2a: Household level variables

\begin{tabular}{lcc}
\hline \hline & Mean & Median \\
\hline Non-housing net wealth & 158,500 & 36,500 \\
Primary home ownership & 0.899 & 1 \\
Primary home value & 100,000 & 80,000 \\
Household non-asset income & 62,500 & 47,500 \\
Number of children & 0.236 & 0 \\
\hline \hline
\end{tabular}

Table $2 b$ : Individual level variables

\begin{tabular}{lcccccccc}
\hline \hline & \multicolumn{2}{c}{ Husband } & \multicolumn{2}{c}{ Wife } & \multicolumn{2}{c}{ Primary earner } & \multicolumn{2}{c}{ Secondary earner } \\
\hline & Mean & Median & Mean & Median & Mean & Median & Mean & Median \\
\hline Age & 58 & 57 & 54 & 54 & 57 & 57 & 54 & 55 \\
Non white & 0.176 & 0 & 0.172 & 0 & 0.176 & 0 & 0.172 & 0 \\
Sex & 0 & 0 & 1 & 1 & 0.183 & 0 & 0.817 & 1 \\
College degree & 0.26 & 0 & 0.191 & 0 & 0.268 & 0 & 0.184 & 0 \\
$\begin{array}{l}\text { Pension coverage } \\
\text { Non-asset income }\end{array}$ & 0.423 & 0 & 0.328 & 0 & 0.472 & 0 & 0.28 & 0 \\
$\begin{array}{l}\text { Actual life } \\
\text { insurance }\end{array}$ & 45,500 & 33,000 & 16,500 & 10,500 & 50,000 & 35,000 & 12,500 & 9,000 \\
$\begin{array}{l}\text { Recommended life } \\
\text { insurance }\end{array}$ & 88,000 & 20,000 & 19,500 & 3,000 & 58,400 & 20,000 & 21,000 & 3,500 \\
$\begin{array}{l}\text { Drop in std. of liv. } \\
\text { if spouse dies }\end{array}$ & $-3.50 \%$ & $0 \%$ & $-8.80 \%$ & $-1.50 \%$ & $-0.81 \%$ & $0 \%$ & $-11.50 \%$ & $-4.50 \%$ \\
\hline \hline
\end{tabular}


Table 3: Change in living standard upon death of spouse, entire population

\begin{tabular}{ccccc}
\hline \hline & Husbands & Wives & Primary earners & Secondary earners \\
\hline$<-40 \%$ & $5.57 \%$ & $14.73 \%$ & $2.96 \%$ & $17.34 \%$ \\
$-40 \%$ to $-20 \%$ & $6.06 \%$ & $15.04 \%$ & $4.69 \%$ & $16.41 \%$ \\
$-20 \%$ to $0 \%$ & $12.74 \%$ & $21.36 \%$ & $13.22 \%$ & $20.88 \%$ \\
$0 \%$ & $29.72 \%$ & $8.01 \%$ & $30.34 \%$ & $7.39 \%$ \\
$0 \%$ to $+20 \%$ & $42.37 \%$ & $29.94 \%$ & $44.80 \%$ & $27.51 \%$ \\
$+20 \%$ to $+40 \%$ & $2.87 \%$ & $6.63 \%$ & $2.74 \%$ & $6.77 \%$ \\
$>+40 \%$ & $0.66 \%$ & $4.29 \%$ & $1.24 \%$ & $3.72 \%$ \\
\hline Observations & 2261 & 2261 & 2261 & 2261 \\
\hline \hline
\end{tabular}


Table 4: Change in living standard upon death of spouse, by household earnings

Table 4a: Household earnings between $\$ 0$ and $\$ 45,000$

\begin{tabular}{ccccc}
\hline \hline & Husbands & Wives & Primary earners & Secondary earners \\
\hline$<-40 \%$ & $7.77 \%$ & $17.26 \%$ & $4.70 \%$ & $20.33 \%$ \\
$-40 \%$ to $-20 \%$ & $6.81 \%$ & $16.40 \%$ & $5.37 \%$ & $17.83 \%$ \\
$-20 \%$ to $0 \%$ & $14.67 \%$ & $22.53 \%$ & $15.34 \%$ & $21.86 \%$ \\
$0 \%$ & $32.12 \%$ & $9.49 \%$ & $33.27 \%$ & $8.34 \%$ \\
$0 \%$ to $+20 \%$ & $36.05 \%$ & $26.46 \%$ & $37.97 \%$ & $24.54 \%$ \\
$+20 \%$ to $+40 \%$ & $2.01 \%$ & $5.18 \%$ & $2.40 \%$ & $4.79 \%$ \\
$>+40 \%$ & $0.58 \%$ & $2.68 \%$ & $0.96 \%$ & $2.30 \%$ \\
\hline Observations & 1043 & 1043 & 1043 & 1043 \\
\hline \hline
\end{tabular}

Table 4b: Household earnings between $\$ 45,000$ and $\$ 100,000$

\begin{tabular}{ccccc}
\hline \hline & Husbands & Wives & Primary earners & Secondary earners \\
\hline$<-40 \%$ & $2.77 \%$ & $11.76 \%$ & $1.78 \%$ & $12.75 \%$ \\
$-40 \%$ to $-20 \%$ & $5.63 \%$ & $14.43 \%$ & $3.95 \%$ & $16.11 \%$ \\
$-20 \%$ to $0 \%$ & $11.66 \%$ & $21.94 \%$ & $12.15 \%$ & $21.44 \%$ \\
$0 \%$ & $27.08 \%$ & $5.83 \%$ & $27.08 \%$ & $5.83 \%$ \\
$0 \%$ to $+20 \%$ & $48.22 \%$ & $32.71 \%$ & $50.69 \%$ & $30.24 \%$ \\
$+20 \%$ to $+40 \%$ & $3.85 \%$ & $8.30 \%$ & $2.96 \%$ & $9.19 \%$ \\
$>+40 \%$ & $0.79 \%$ & $5.04 \%$ & $1.38 \%$ & $4.45 \%$ \\
\hline Observations & 1012 & 1012 & 1012 & 1012 \\
\hline \hline
\end{tabular}

Table 4c: Household earnings above $\$ 100,000$

\begin{tabular}{ccccc}
\hline \hline & Husbands & Wives & Primary earners & Secondary earners \\
\hline$<-40 \%$ & $8.54 \%$ & $17.09 \%$ & $0.00 \%$ & $25.63 \%$ \\
$-40 \%$ to $-20 \%$ & $4.52 \%$ & $11.56 \%$ & $5.03 \%$ & $11.06 \%$ \\
$-20 \%$ to $0 \%$ & $8.54 \%$ & $12.56 \%$ & $8.04 \%$ & $13.07 \%$ \\
$0 \%$ & $28.64 \%$ & $10.05 \%$ & $29.65 \%$ & $9.05 \%$ \\
$0 \%$ to $+20 \%$ & $46.73 \%$ & $33.67 \%$ & $51.76 \%$ & $28.64 \%$ \\
$+20 \%$ to $+40 \%$ & $2.51 \%$ & $6.03 \%$ & $3.52 \%$ & $5.03 \%$ \\
$>+40 \%$ & $0.50 \%$ & $9.05 \%$ & $2.01 \%$ & $7.54 \%$ \\
\hline Observations & 199 & 199 & 199 & 199 \\
\hline \hline
\end{tabular}

Table 5: Changes in living standard upon death of spouse, by single/dual earners 
Table 5a: Single earners

\begin{tabular}{ccccc}
\hline \hline & Husbands & Wives & Primary earners & Secondary earners \\
\hline$<-40 \%$ & $2.61 \%$ & $20.04 \%$ & $1.40 \%$ & $21.24 \%$ \\
$-40 \%$ to $-20 \%$ & $0.60 \%$ & $13.83 \%$ & $0.40 \%$ & $14.03 \%$ \\
$-20 \%$ to $0 \%$ & $4.41 \%$ & $19.04 \%$ & $4.61 \%$ & $18.84 \%$ \\
$0 \%$ & $47.70 \%$ & $7.01 \%$ & $48.10 \%$ & $6.61 \%$ \\
$0 \%$ to $+20 \%$ & $42.28 \%$ & $27.25 \%$ & $43.09 \%$ & $26.45 \%$ \\
$+20 \%$ to $+40 \%$ & $1.60 \%$ & $7.62 \%$ & $1.60 \%$ & $7.62 \%$ \\
$>+40 \%$ & $0.80 \%$ & $5.21 \%$ & $0.80 \%$ & $5.21 \%$ \\
\hline Observations & 499 & 499 & 499 & 499 \\
\hline \hline
\end{tabular}

Table 5b: Dual earners

\begin{tabular}{ccccc}
\hline \hline & Husbands & Wives & Primary earners & Secondary earners \\
\hline$<-40 \%$ & $6.41 \%$ & $13.22 \%$ & $3.41 \%$ & $16.23 \%$ \\
$-40 \%$ to $-20 \%$ & $7.60 \%$ & $15.38 \%$ & $5.90 \%$ & $17.08 \%$ \\
$-20 \%$ to $0 \%$ & $15.10 \%$ & $22.02 \%$ & $15.66 \%$ & $21.45 \%$ \\
$0 \%$ & $24.63 \%$ & $8.29 \%$ & $25.31 \%$ & $7.60 \%$ \\
$0 \%$ to $+20 \%$ & $42.40 \%$ & $30.70 \%$ & $45.29 \%$ & $27.81 \%$ \\
$+20 \%$ to $+40 \%$ & $3.23 \%$ & $6.36 \%$ & $3.06 \%$ & $6.53 \%$ \\
$>+40 \%$ & $0.62 \%$ & $4.03 \%$ & $1.36 \%$ & $3.29 \%$ \\
\hline Observations & 1762 & 1762 & 1762 & 1762 \\
\hline \hline
\end{tabular}


Table 6: Change in living standard upon death of spouse, by relative earnings (ratio of husband's/wife's earnings, or primary/secondary earnings)

Table 6a: Relative income between 0 and 1

\begin{tabular}{ccccc}
\hline \hline & Husbands & Wives & Primary earners & Secondary earners \\
\hline$<-40 \%$ & $20.58 \%$ & $6.30 \%$ & NA & NA \\
$-40 \%$ to $-20 \%$ & $16.71 \%$ & $9.20 \%$ & NA & NA \\
$-20 \%$ to $0 \%$ & $20.58 \%$ & $23.24 \%$ & NA & NA \\
$0 \%$ & $11.14 \%$ & $14.53 \%$ & NA & NA \\
$0 \%$ to $+20 \%$ & $25.42 \%$ & $38.74 \%$ & NA & NA \\
$+20 \%$ to $+40 \%$ & $4.60 \%$ & $3.87 \%$ & NA & NA \\
$>+40 \%$ & $0.97 \%$ & $4.12 \%$ & NA & NA \\
\hline Observations & 413 & 413 & 0 & 0 \\
\hline \hline
\end{tabular}

Table 6b: Relative income between 1 and 2

\begin{tabular}{ccccc}
\hline \hline & Husbands & Wives & Primary earners & Secondary earners \\
\hline$<-40 \%$ & $4.57 \%$ & $7.75 \%$ & $5.91 \%$ & $10.10 \%$ \\
$-40 \%$ to $-20 \%$ & $10.34 \%$ & $16.90 \%$ & $10.63 \%$ & $17.19 \%$ \\
$-20 \%$ to $0 \%$ & $24.06 \%$ & $25.25 \%$ & $25.20 \%$ & $24.67 \%$ \\
$0 \%$ & $15.71 \%$ & $8.15 \%$ & $13.91 \%$ & $8.53 \%$ \\
$0 \%$ to $+20 \%$ & $41.15 \%$ & $32.41 \%$ & $39.11 \%$ & $31.50 \%$ \\
$+20 \%$ to $+40 \%$ & $3.58 \%$ & $6.56 \%$ & $3.41 \%$ & $5.64 \%$ \\
$>+40 \%$ & $0.60 \%$ & $2.98 \%$ & $1.84 \%$ & $2.36 \%$ \\
\hline Observations & 503 & 503 & 762 & 762 \\
\hline \hline
\end{tabular}

Table 6c: Relative income between 2 and 4

\begin{tabular}{ccccc}
\hline \hline & Husbands & Wives & Primary earners & Secondary earners \\
\hline$<-40 \%$ & $2.59 \%$ & $13.99 \%$ & $2.78 \%$ & $16.06 \%$ \\
$-40 \%$ to $-20 \%$ & $2.85 \%$ & $18.91 \%$ & $4.07 \%$ & $18.84 \%$ \\
$-20 \%$ to $0 \%$ & $12.44 \%$ & $23.32 \%$ & $13.49 \%$ & $21.84 \%$ \\
$0 \%$ & $25.91 \%$ & $5.70 \%$ & $23.55 \%$ & $7.71 \%$ \\
$0 \%$ to $+20 \%$ & $51.55 \%$ & $26.94 \%$ & $50.54 \%$ & $25.48 \%$ \\
$+20 \%$ to $+40 \%$ & $3.89 \%$ & $6.99 \%$ & $4.28 \%$ & $6.42 \%$ \\
$>+40 \%$ & $0.78 \%$ & $4.15 \%$ & $1.28 \%$ & $3.64 \%$ \\
\hline Observations & 386 & 386 & 467 & 467 \\
\hline \hline
\end{tabular}

Table 6d: Relative income above 4

\begin{tabular}{ccccc}
\hline \hline & Husbands & Wives & Primary earners & Secondary earners \\
\hline$<-40 \%$ & $0.84 \%$ & $22.23 \%$ & $0.87 \%$ & $23.18 \%$ \\
$-40 \%$ to $-20 \%$ & $0.52 \%$ & $15.03 \%$ & $0.58 \%$ & $14.74 \%$ \\
$-20 \%$ to $0 \%$ & $3.55 \%$ & $17.75 \%$ & $4.27 \%$ & $17.65 \%$ \\
$0 \%$ & $46.56 \%$ & $6.05 \%$ & $45.49 \%$ & $6.40 \%$ \\
$0 \%$ to $+20 \%$ & $46.66 \%$ & $26.10 \%$ & $46.46 \%$ & $25.51 \%$ \\
$+20 \%$ to $+40 \%$ & $1.36 \%$ & $7.72 \%$ & $1.55 \%$ & $7.76 \%$ \\
$>+40 \%$ & $0.52 \%$ & $5.11 \%$ & $0.78 \%$ & $4.75 \%$ \\
\hline Observations & 958 & 958 & 1031 & 1031 \\
\hline \hline
\end{tabular}


Table 7: Change in living standard upon death of spouse, by age

Table $7 a: 40 s$

\begin{tabular}{ccccc}
\hline \hline & Husbands & Wives & Primary earners & Secondary earners \\
\hline$<-40 \%$ & $6.12 \%$ & $20.49 \%$ & $6.42 \%$ & $22.90 \%$ \\
$-40 \%$ to $-20 \%$ & $16.33 \%$ & $22.22 \%$ & $8.26 \%$ & $25.80 \%$ \\
$-20 \%$ to $0 \%$ & $16.33 \%$ & $22.47 \%$ & $20.18 \%$ & $22.32 \%$ \\
$0 \%$ & $18.37 \%$ & $3.95 \%$ & $10.09 \%$ & $4.06 \%$ \\
$0 \%$ to $+20 \%$ & $36.73 \%$ & $21.48 \%$ & $49.54 \%$ & $14.78 \%$ \\
$+20 \%$ to $+40 \%$ & $2.04 \%$ & $4.94 \%$ & $2.75 \%$ & $5.22 \%$ \\
$>+40 \%$ & $4.08 \%$ & $4.44 \%$ & $2.75 \%$ & $4.93 \%$ \\
\hline Observations & 49 & 405 & 109 & 345 \\
\hline \hline
\end{tabular}

Table $7 b: 50 s$

\begin{tabular}{ccccc}
\hline \hline & Husbands & Wives & Primary earners & Secondary earners \\
\hline$<-40 \%$ & $6.00 \%$ & $15.02 \%$ & $2.66 \%$ & $18.52 \%$ \\
$-40 \%$ to $-20 \%$ & $6.57 \%$ & $14.54 \%$ & $5.18 \%$ & $16.07 \%$ \\
$-20 \%$ to $0 \%$ & $13.13 \%$ & $21.74 \%$ & $13.80 \%$ & $21.24 \%$ \\
$0 \%$ & $29.19 \%$ & $8.09 \%$ & $30.60 \%$ & $6.29 \%$ \\
$0 \%$ to $+20 \%$ & $41.26 \%$ & $29.70 \%$ & $43.21 \%$ & $27.53 \%$ \\
$+20 \%$ to $+40 \%$ & $3.21 \%$ & $6.72 \%$ & $3.29 \%$ & $6.71 \%$ \\
$>+40 \%$ & $0.64 \%$ & $4.18 \%$ & $1.26 \%$ & $3.63 \%$ \\
\hline Observations & 1401 & 1458 & 1428 & 1431 \\
\hline \hline
\end{tabular}

Table 7c: $60 \mathrm{~s}$

\begin{tabular}{ccccc}
\hline \hline & Husbands & Wives & Primary earners & Secondary earners \\
\hline$<-40 \%$ & $4.09 \%$ & $4.96 \%$ & $2.10 \%$ & $8.05 \%$ \\
$-40 \%$ to $-20 \%$ & $3.95 \%$ & $9.62 \%$ & $3.15 \%$ & $10.00 \%$ \\
$-20 \%$ to $0 \%$ & $11.58 \%$ & $18.08 \%$ & $10.64 \%$ & $18.54 \%$ \\
$0 \%$ & $31.06 \%$ & $11.95 \%$ & $32.08 \%$ & $13.41 \%$ \\
$0 \%$ to $+20 \%$ & $46.32 \%$ & $42.86 \%$ & $49.18 \%$ & $38.78 \%$ \\
$+20 \%$ to $+40 \%$ & $2.59 \%$ & $7.87 \%$ & $1.80 \%$ & $8.29 \%$ \\
$>+40 \%$ & $0.41 \%$ & $4.66 \%$ & $1.05 \%$ & $2.93 \%$ \\
\hline Observations & 734 & 343 & 667 & 410 \\
\hline \hline
\end{tabular}

Table 8: Change in living standard upon death of spouse, by number of children 
Table 8a: No children

\begin{tabular}{ccccc}
\hline \hline & Husbands & Wives & Primary earners & Secondary earners \\
\hline$<-40 \%$ & $4.99 \%$ & $13.02 \%$ & $2.23 \%$ & $15.78 \%$ \\
$-40 \%$ to $-20 \%$ & $5.69 \%$ & $14.08 \%$ & $4.52 \%$ & $15.25 \%$ \\
$-20 \%$ to $0 \%$ & $12.59 \%$ & $21.20 \%$ & $13.02 \%$ & $20.78 \%$ \\
$0 \%$ & $29.97 \%$ & $8.71 \%$ & $30.50 \%$ & $8.18 \%$ \\
$0 \%$ to $+20 \%$ & $43.20 \%$ & $31.56 \%$ & $45.59 \%$ & $29.17 \%$ \\
$+20 \%$ to $+40 \%$ & $2.98 \%$ & $7.01 \%$ & $2.98 \%$ & $7.01 \%$ \\
$>+40 \%$ & $0.58 \%$ & $4.41 \%$ & $1.17 \%$ & $3.83 \%$ \\
\hline Observations & 1882 & 1882 & 1882 & 1882 \\
\hline \hline
\end{tabular}

Table 8b: One child or more

\begin{tabular}{ccccc}
\hline \hline & Husbands & Wives & Primary earners & Secondary earners \\
\hline$<-40 \%$ & $8.44 \%$ & $23.22 \%$ & $6.60 \%$ & $25.07 \%$ \\
$-40 \%$ to $-20 \%$ & $7.92 \%$ & $19.79 \%$ & $5.54 \%$ & $22.16 \%$ \\
$-20 \%$ to $0 \%$ & $13.46 \%$ & $22.16 \%$ & $14.25 \%$ & $21.37 \%$ \\
$0 \%$ & $28.50 \%$ & $4.49 \%$ & $29.55 \%$ & $3.43 \%$ \\
$0 \%$ to $+20 \%$ & $38.26 \%$ & $21.90 \%$ & $40.90 \%$ & $19.26 \%$ \\
$+20 \%$ to $+40 \%$ & $2.37 \%$ & $4.75 \%$ & $1.58 \%$ & $5.54 \%$ \\
$>+40 \%$ & $1.06 \%$ & $3.69 \%$ & $1.58 \%$ & $3.17 \%$ \\
\hline Observations & 379 & 379 & 379 & 379 \\
\hline \hline
\end{tabular}


Table 9: Change in living standard upon death of spouse, by ethnicity

Table 9a: Whites

\begin{tabular}{ccccc}
\hline \hline & Husbands & Wives & Primary earners & Secondary earners \\
\hline$<-40 \%$ & $4.12 \%$ & $12.78 \%$ & $1.66 \%$ & $15.23 \%$ \\
$-40 \%$ to $-20 \%$ & $5.18 \%$ & $13.90 \%$ & $3.74 \%$ & $15.34 \%$ \\
$-20 \%$ to $0 \%$ & $11.38 \%$ & $21.73 \%$ & $11.97 \%$ & $21.14 \%$ \\
$0 \%$ & $30.57 \%$ & $7.88 \%$ & $30.84 \%$ & $7.61 \%$ \\
$0 \%$ to $+20 \%$ & $45.22 \%$ & $31.63 \%$ & $47.78 \%$ & $29.07 \%$ \\
$+20 \%$ to $+40 \%$ & $2.73 \%$ & $7.40 \%$ & $2.67 \%$ & $7.45 \%$ \\
$>+40 \%$ & $0.80 \%$ & $4.69 \%$ & $1.34 \%$ & $4.15 \%$ \\
\hline Observations & 1871 & 1878 & 1871 & 1878 \\
\hline \hline
\end{tabular}

Table 9b: Non-whites

\begin{tabular}{ccccc}
\hline \hline & Husbands & Wives & Primary earners & Secondary earners \\
\hline$<-40 \%$ & $12.56 \%$ & $24.28 \%$ & $9.23 \%$ & $27.68 \%$ \\
$-40 \%$ to $-20 \%$ & $10.26 \%$ & $20.63 \%$ & $9.23 \%$ & $21.67 \%$ \\
$-20 \%$ to $0 \%$ & $19.23 \%$ & $19.58 \%$ & $19.23 \%$ & $19.58 \%$ \\
$0 \%$ & $25.64 \%$ & $8.62 \%$ & $27.95 \%$ & $6.27 \%$ \\
$0 \%$ to $+20 \%$ & $28.72 \%$ & $21.67 \%$ & $30.51 \%$ & $19.84 \%$ \\
$+20 \%$ to $+40 \%$ & $3.59 \%$ & $2.87 \%$ & $3.08 \%$ & $3.39 \%$ \\
$>+40 \%$ & $0.00 \%$ & $2.35 \%$ & $0.77 \%$ & $1.57 \%$ \\
\hline Observations & 390 & 383 & 390 & 383 \\
\hline \hline
\end{tabular}


Table 10: Sensitivity to the real interest rate assumption

Table 10a: $1 \%$ interest rate

\begin{tabular}{ccccc}
\hline \hline & Husbands & Wives & Primary earners & Secondary earners \\
\hline$<-40 \%$ & $4.98 \%$ & $12.79 \%$ & $2.53 \%$ & $15.24 \%$ \\
$-40 \%$ to $-20 \%$ & $5.91 \%$ & $16.04 \%$ & $4.66 \%$ & $17.28 \%$ \\
$-20 \%$ to $0 \%$ & $14.70 \%$ & $24.74 \%$ & $15.15 \%$ & $24.30 \%$ \\
$0 \%$ & $29.41 \%$ & $7.86 \%$ & $30.08 \%$ & $7.20 \%$ \\
$0 \%$ to $+20 \%$ & $42.65 \%$ & $30.56 \%$ & $44.91 \%$ & $28.30 \%$ \\
$+20 \%$ to $+40 \%$ & $1.91 \%$ & $5.64 \%$ & $1.87 \%$ & $5.69 \%$ \\
$>+40 \%$ & $0.44 \%$ & $2.35 \%$ & $0.80 \%$ & $2.00 \%$ \\
\hline Observations & 2251 & 2251 & 2251 & 2251 \\
\hline \hline
\end{tabular}

Table 10b: $5 \%$ interest rate

\begin{tabular}{ccccc}
\hline \hline & Husbands & Wives & Primary earners & Secondary earners \\
\hline$<-40 \%$ & $6.06 \%$ & $16.19 \%$ & $3.18 \%$ & $19.06 \%$ \\
$-40 \%$ to $-20 \%$ & $5.84 \%$ & $13.05 \%$ & $4.38 \%$ & $14.51 \%$ \\
$-20 \%$ to $0 \%$ & $11.46 \%$ & $19.24 \%$ & $12.38 \%$ & $18.31 \%$ \\
$0 \%$ & $29.85 \%$ & $8.27 \%$ & $30.52 \%$ & $7.61 \%$ \\
$0 \%$ to $+20 \%$ & $41.53 \%$ & $29.23 \%$ & $43.48 \%$ & $27.29 \%$ \\
$+20 \%$ to $+40 \%$ & $4.16 \%$ & $7.87 \%$ & $4.33 \%$ & $7.70 \%$ \\
$>+40 \%$ & $1.11 \%$ & $6.15 \%$ & $1.72 \%$ & $5.53 \%$ \\
\hline Observations & 2261 & 2261 & 2261 & 2261 \\
\hline \hline
\end{tabular}


Table 11: Sensitivity to the growth rate assumption

Table 11a: 0\% growth rate

\begin{tabular}{ccccc}
\hline \hline & Husbands & Wives & Primary earners & Secondary earners \\
\hline$<-40 \%$ & $5.09 \%$ & $13.37 \%$ & $2.74 \%$ & $15.71 \%$ \\
$-40 \%$ to $-20 \%$ & $5.49 \%$ & $14.25 \%$ & $4.29 \%$ & $15.45 \%$ \\
$-20 \%$ to $0 \%$ & $12.97 \%$ & $21.34 \%$ & $13.10 \%$ & $21.20 \%$ \\
$0 \%$ & $29.97 \%$ & $8.41 \%$ & $30.54 \%$ & $7.84 \%$ \\
$0 \%$ to $+20 \%$ & $42.85 \%$ & $30.54 \%$ & $45.02 \%$ & $28.38 \%$ \\
$+20 \%$ to $+40 \%$ & $2.79 \%$ & $7.44 \%$ & $2.92 \%$ & $7.30 \%$ \\
$>+40 \%$ & $0.84 \%$ & $4.65 \%$ & $1.37 \%$ & $4.12 \%$ \\
\hline Observations & 2259 & 2259 & 2259 & 2259 \\
\hline \hline
\end{tabular}

Table 11b: $2 \%$ growth rate

\begin{tabular}{ccccc}
\hline \hline & Husbands & Wives & Primary earners & Secondary earners \\
\hline$<-40 \%$ & $5.62 \%$ & $14.90 \%$ & $3.01 \%$ & $17.51 \%$ \\
$-40 \%$ to $-20 \%$ & $6.15 \%$ & $15.04 \%$ & $4.78 \%$ & $16.41 \%$ \\
$-20 \%$ to $0 \%$ & $12.83 \%$ & $21.27 \%$ & $13.31 \%$ & $20.79 \%$ \\
$0 \%$ & $29.68 \%$ & $8.05 \%$ & $30.30 \%$ & $7.43 \%$ \\
$0 \%$ to $+20 \%$ & $42.24 \%$ & $29.85 \%$ & $44.67 \%$ & $27.42 \%$ \\
$+20 \%$ to $+40 \%$ & $2.83 \%$ & $6.63 \%$ & $2.74 \%$ & $6.72 \%$ \\
$>+40 \%$ & $0.66 \%$ & $4.25 \%$ & $1.19 \%$ & $3.72 \%$ \\
\hline Observations & 2261 & 2261 & 2261 & 2261 \\
\hline \hline
\end{tabular}


Table 12: Quantile Regression Results for Husbands and Wives

\begin{tabular}{|c|c|c|c|c|c|c|}
\hline & \multicolumn{3}{|c|}{ Wives } & \multicolumn{3}{|c|}{ Husbands } \\
\hline & $25 \%$ & $50 \%$ & $75 \%$ & $25 \%$ & $50 \%$ & $75 \%$ \\
\hline $\begin{array}{l}\text { Non-asset } \\
\text { income (couple) }\end{array}$ & $\begin{array}{l}-1.59 e-5 \\
(1.07 e-5)\end{array}$ & $\begin{array}{c}-8.84 \mathrm{e}-6 \\
(7.12 \mathrm{e}-06)\end{array}$ & $\begin{array}{l}-7.47 e-6 \\
(9.99 e-6)\end{array}$ & $\begin{array}{l}-1.37 \mathrm{e}-6 \\
(1.48 \mathrm{e}-6)\end{array}$ & $\begin{array}{c}-1.07 \mathrm{e}-7 \\
(3.18 \mathrm{e}-7)\end{array}$ & $\begin{array}{l}-6.91 \mathrm{e}-7 \\
(7.49 \mathrm{e}-7)\end{array}$ \\
\hline $\begin{array}{l}\text { Spouse's } \\
\text { earnings share }\end{array}$ & $\begin{array}{l}-24.7^{* *} \\
(3.68)\end{array}$ & $\begin{array}{l}-9.37^{* *} \\
(3.24)\end{array}$ & $\begin{array}{c}2.02 \\
(3.05)\end{array}$ & $\begin{array}{l}-16.1^{* *} \\
(3.95)\end{array}$ & $\begin{array}{l}-0.811 \\
(0.524)\end{array}$ & $\begin{array}{c}0.260 \\
(1.09)\end{array}$ \\
\hline $\begin{array}{l}\text { Asset to income } \\
\text { ratio }\end{array}$ & $\begin{array}{l}1.16 \mathrm{e}-5 \\
(0.157)\end{array}$ & $\begin{array}{c}-1.00 \mathrm{e}-5 \\
(0.141)\end{array}$ & $\begin{array}{c}-2.73 \mathrm{e}-5 \\
(0.114)\end{array}$ & $\begin{array}{c}12.4 \mathrm{e}-5 \\
(0.0194)\end{array}$ & $\begin{array}{c}2.77 \mathrm{e}-5 \\
(0.0120)\end{array}$ & $\begin{array}{c}-0.486 \mathrm{e}-5 \\
(0.0120)\end{array}$ \\
\hline Age (self) & $\begin{array}{l}0.891^{* *} \\
(0.171)\end{array}$ & $\begin{array}{l}0.685^{* *} \\
(0.151)\end{array}$ & $\begin{array}{l}0.362^{* *} \\
(0.130)\end{array}$ & $\begin{array}{l}-0.0114 \\
(0.0319)\end{array}$ & $\begin{array}{c}0.00263 \\
(0.0105)\end{array}$ & $\begin{array}{c}0.0255 \\
(0.0346)\end{array}$ \\
\hline Age (spouse) & $\begin{array}{l}0.844^{* *} \\
(0.176)\end{array}$ & $\begin{array}{c}0.348^{*} \\
(0.138)\end{array}$ & $\begin{array}{l}-0.130 \\
(0.119)\end{array}$ & $\begin{array}{c}0.0922 \\
(0.0539)\end{array}$ & $\begin{array}{c}0.0229^{*} \\
(0.0120)\end{array}$ & $\begin{array}{r}-0.00197 \\
(0.0332)\end{array}$ \\
\hline $\begin{array}{l}\text { Number of } \\
\text { dependents }\end{array}$ & $\begin{array}{l}-1.39 \\
(1.28)\end{array}$ & $\begin{array}{l}-0.766 \\
(1.25)\end{array}$ & $\begin{array}{l}-1.86 \\
(1.06)\end{array}$ & $\begin{array}{l}-13.7^{* *} \\
(1.82)\end{array}$ & $\begin{array}{l}-6.04^{* *} \\
(2.11)\end{array}$ & $\begin{array}{c}-1.10 \\
(0.598)\end{array}$ \\
\hline $\begin{array}{l}\text { Race (head of } \\
\text { household) }\end{array}$ & $\begin{array}{l}-14.0^{* *} \\
(2.48)\end{array}$ & $\begin{array}{l}-10.5^{* *} \\
(2.36)\end{array}$ & $\begin{array}{l}-5.87^{* *} \\
(1.29)\end{array}$ & $\begin{array}{l}-3.40 \\
(2.01)\end{array}$ & $\begin{array}{l}-0.355^{*} \\
(0.180)\end{array}$ & $\begin{array}{l}-0.383 \\
(0.386)\end{array}$ \\
\hline $\begin{array}{l}\text { College (head of } \\
\text { household) }\end{array}$ & $\begin{array}{l}5.36^{* *} \\
(1.79)\end{array}$ & $\begin{array}{l}5.76^{* *} \\
(1.16)\end{array}$ & $\begin{array}{l}7.95^{* *} \\
(1.55)\end{array}$ & $\begin{array}{c}0.135 \\
(0.220)\end{array}$ & $\begin{array}{c}0.177 \\
(0.149)\end{array}$ & $\begin{array}{c}0.764 \\
(0.413)\end{array}$ \\
\hline Pension (self) & $\begin{array}{l}3.94^{*} \\
(1.79)\end{array}$ & $\begin{array}{l}3.35^{* *} \\
(1.26)\end{array}$ & $\begin{array}{c}1.19 \\
(1.13)\end{array}$ & $\begin{array}{c}0.182 \\
(0.207)\end{array}$ & $\begin{array}{l}0.0345 \\
(0.125)\end{array}$ & $\begin{array}{c}0.302 \\
(0.322)\end{array}$ \\
\hline Pension (spouse) & $\begin{array}{c}1.37 \\
(2.14)\end{array}$ & $\begin{array}{l}-1.35 \\
(1.43)\end{array}$ & $\begin{array}{l}0.924 \\
(1.23)\end{array}$ & $\begin{array}{l}2.94^{* *} \\
(0.856)\end{array}$ & $\begin{array}{c}1.05^{* *} \\
(0.296)\end{array}$ & $\begin{array}{c}3.14^{* *} \\
(0.509)\end{array}$ \\
\hline Homeowner & $\begin{array}{l}43.2^{* *} \\
(5.69)\end{array}$ & $\begin{array}{l}27.0^{* *} \\
(3.43)\end{array}$ & $\begin{array}{l}11.2^{* *} \\
(2.92)\end{array}$ & $\begin{array}{l}27.0^{* *} \\
(5.50)\end{array}$ & $\begin{array}{l}0.778 \\
(2.08)\end{array}$ & $\begin{array}{c}1.88^{* *} \\
(0.340)\end{array}$ \\
\hline $\begin{array}{l}\text { Survival prob. } \\
\text { (self) }\end{array}$ & $\begin{array}{l}-0.0187 \\
(0.282)\end{array}$ & $\begin{array}{c}0.222 \\
(0.215)\end{array}$ & $\begin{array}{c}0.175 \\
(0.182)\end{array}$ & $\begin{array}{c}0.0793 \\
(0.0452)\end{array}$ & $\begin{array}{c}0.0287 \\
(0.0204)\end{array}$ & $\begin{array}{c}0.0356 \\
(0.0524)\end{array}$ \\
\hline $\begin{array}{l}\text { Survival prob. } \\
\text { (spouse) }\end{array}$ & $\begin{array}{c}0.0988 \\
(0.250)\end{array}$ & $\begin{array}{r}-0.0153 \\
(0.183)\end{array}$ & $\begin{array}{c}0.181 \\
(0.183)\end{array}$ & $\begin{array}{c}0.0106 \\
(0.0379)\end{array}$ & $\begin{array}{c}0.0155 \\
(0.0168)\end{array}$ & $\begin{array}{c}0.0210 \\
(0.0505)\end{array}$ \\
\hline Constant & $\begin{array}{l}-142^{* *} \\
(12.0)\end{array}$ & $\begin{array}{c}-82.9^{* *} \\
(10.1)\end{array}$ & $\begin{array}{l}-19.8^{*} \\
(8.65)\end{array}$ & $\begin{array}{c}-31.6^{* *} \\
(5.42)\end{array}$ & $\begin{array}{c}-2.14 \\
(2.30)\end{array}$ & $\begin{array}{l}-1.56 \\
(2.06)\end{array}$ \\
\hline
\end{tabular}

\footnotetext{
* $\quad$ Significant at $95 \%$ confidence level

** $\quad$ Significant at $99 \%$ confidence level
} 
Table 13: Quantile Regression Results for Primary and Secondary Earners

\begin{tabular}{|c|c|c|c|c|c|c|}
\hline & \multicolumn{3}{|c|}{ Secondary Earner } & \multicolumn{3}{|c|}{ Primary Earner } \\
\hline & $25 \%$ & $50 \%$ & $75 \%$ & $25 \%$ & $50 \%$ & $75 \%$ \\
\hline $\begin{array}{l}\text { Non-asset } \\
\text { income (couple) }\end{array}$ & $\begin{array}{l}-2.74 e-5 \\
(2.43 e-5)\end{array}$ & $\begin{array}{l}-9.91 e-6 \\
(9.84 e-6)\end{array}$ & $\begin{array}{r}-0.118 e-6 \\
(8.27 e-6)\end{array}$ & $\begin{array}{l}-1.69 \mathrm{e}-7 \\
(4.50 \mathrm{e}-7)\end{array}$ & $\begin{array}{l}-1.16 \mathrm{e}-7 \\
(2.78 \mathrm{e}-7)\end{array}$ & $\begin{array}{l}-7.77 \mathrm{e}-7 \\
(21.4 \mathrm{e}-7)\end{array}$ \\
\hline $\begin{array}{l}\text { Spouse's } \\
\text { earnings share }\end{array}$ & $\begin{array}{l}-36.1^{* *} \\
(6.06)\end{array}$ & $\begin{array}{l}-12.0^{* *} \\
(3.94)\end{array}$ & $\begin{array}{l}-0.631 \\
(3.81)\end{array}$ & $\begin{array}{l}-14.3^{* *} \\
(3.14)\end{array}$ & $\begin{array}{l}-0.789 \\
(0.467)\end{array}$ & $\begin{array}{c}2.90 \\
(1.73)\end{array}$ \\
\hline $\begin{array}{l}\text { Asset to income } \\
\text { ratio }\end{array}$ & $\begin{array}{l}14.2 \mathrm{e}-5 \\
(0.175)\end{array}$ & $\begin{array}{l}4.26 \mathrm{e}-5 \\
(0.187)\end{array}$ & $\begin{array}{c}-1.31 \mathrm{e}-5 \\
(0.141)\end{array}$ & $\begin{array}{c}1.34 \mathrm{e}-6 \\
(0.00999)\end{array}$ & $\begin{array}{c}1.08 \mathrm{e}-6 \\
(0.00357)\end{array}$ & $\begin{array}{c}-7.69 e-6 \\
(0.00894)\end{array}$ \\
\hline Age (self) & $\begin{array}{l}0.734^{* *} \\
(0.153)\end{array}$ & $\begin{array}{l}0.649^{* *} \\
(0.158)\end{array}$ & $\begin{array}{c}0.277^{*} \\
(0.121)\end{array}$ & $\begin{array}{c}-0.00676 \\
(0.0191)\end{array}$ & $\begin{array}{l}-0.00218 \\
(0.00659)\end{array}$ & $\begin{array}{l}-0.0283 \\
(0.0381)\end{array}$ \\
\hline Age (spouse) & $\begin{array}{l}1.62^{* *} \\
(0.146)\end{array}$ & $\begin{array}{l}0.939^{* *} \\
(0.165)\end{array}$ & $\begin{array}{l}0.452^{* *} \\
(0.154)\end{array}$ & $\begin{array}{c}0.0209 \\
(0.0224)\end{array}$ & $\begin{array}{c}0.00219 \\
(0.00712)\end{array}$ & $\begin{array}{r}-0.00579 \\
(0.0459)\end{array}$ \\
\hline $\begin{array}{l}\text { Number of } \\
\text { dependents }\end{array}$ & $\begin{array}{l}-1.14 \\
(1.68)\end{array}$ & $\begin{array}{l}0.244 \\
(1.74)\end{array}$ & $\begin{array}{l}-0.348 \\
(1.38)\end{array}$ & $\begin{array}{c}4.51 \\
(3.68)\end{array}$ & $\begin{array}{c}0.150 \\
(0.911)\end{array}$ & $\begin{array}{l}-0.924 \\
(1.30)\end{array}$ \\
\hline $\begin{array}{l}\text { Race (head of } \\
\text { household) }\end{array}$ & $\begin{array}{l}-13.0^{* *} \\
(2.57)\end{array}$ & $\begin{array}{l}-10.3^{* *} \\
(2.35)\end{array}$ & $\begin{array}{l}-5.38^{* *} \\
(1.44)\end{array}$ & $\begin{array}{l}-6.12^{* *} \\
(2.03)\end{array}$ & $\begin{array}{l}-0.288 \\
(0.151)\end{array}$ & $\begin{array}{l}-0.588 \\
(0.459)\end{array}$ \\
\hline $\begin{array}{l}\text { College (head of } \\
\text { household) }\end{array}$ & $\begin{array}{l}4.11^{*} \\
(1.95)\end{array}$ & $\begin{array}{l}4.40^{* *} \\
(1.37)\end{array}$ & $\begin{array}{l}7.42^{* *} \\
(1.61)\end{array}$ & $\begin{array}{c}0.377 \\
(0.213)\end{array}$ & $\begin{array}{c}0.182 \\
(0.152)\end{array}$ & $\begin{array}{c}0.844 \\
(0.582)\end{array}$ \\
\hline Pension (self) & $\begin{array}{c}2.02 \\
(1.95)\end{array}$ & $\begin{array}{c}3.53^{*} \\
(1.44)\end{array}$ & $\begin{array}{c}1.93 \\
(1.39)\end{array}$ & $\begin{array}{c}0.00966 \\
(0.126)\end{array}$ & $\begin{array}{c}0.0216 \\
(0.0877)\end{array}$ & $\begin{array}{c}0.159 \\
(0.410)\end{array}$ \\
\hline Pension (spouse) & $\begin{array}{c}2.83 \\
(1.93)\end{array}$ & $\begin{array}{l}-0.456 \\
(1.55)\end{array}$ & $\begin{array}{c}2.07 \\
(1.25)\end{array}$ & $\begin{array}{c}2.44^{* *} \\
(0.626)\end{array}$ & $\begin{array}{c}1.13^{* *} \\
(0.270)\end{array}$ & $\begin{array}{c}2.50^{* *} \\
(0.683)\end{array}$ \\
\hline Homeowner & $\begin{array}{l}44.2^{* *} \\
(4.41)\end{array}$ & $\begin{array}{l}28.2^{* *} \\
(3.86)\end{array}$ & $\begin{array}{l}13.4^{* *} \\
(4.43)\end{array}$ & $\begin{array}{l}23.6^{* *} \\
(4.45)\end{array}$ & $\begin{array}{l}0.929 \\
(1.07)\end{array}$ & $\begin{array}{c}1.89^{* *} \\
(0.393)\end{array}$ \\
\hline $\begin{array}{l}\text { Survival prob. } \\
\text { (self) }\end{array}$ & $\begin{array}{c}0.295 \\
(0.269)\end{array}$ & $\begin{array}{c}0.409 \\
(0.244)\end{array}$ & $\begin{array}{c}0.319 \\
(0.198)\end{array}$ & $\begin{array}{c}0.0175 \\
(0.0251)\end{array}$ & $\begin{array}{l}0.00362 \\
(0.0141)\end{array}$ & $\begin{array}{c}0.0304 \\
(0.0596)\end{array}$ \\
\hline $\begin{array}{l}\text { Survival prob. } \\
\text { (spouse) }\end{array}$ & $\begin{array}{c}0.00728 \\
(0.253)\end{array}$ & $\begin{array}{c}-0.00799 \\
(0.229)\end{array}$ & $\begin{array}{l}-0.167 \\
(0.184)\end{array}$ & $\begin{array}{c}0.00820 \\
(0.0227)\end{array}$ & $\begin{array}{c}0.00258 \\
(0.0123)\end{array}$ & $\begin{array}{c}0.0356 \\
(0.0532)\end{array}$ \\
\hline Constant & $\begin{array}{l}-172^{* *} \\
(12.7)\end{array}$ & $\begin{array}{l}-118^{* *} \\
(12.4)\end{array}$ & $\begin{array}{l}-50.7^{* *} \\
(12.0)\end{array}$ & $\begin{array}{l}-24.4^{* *} \\
(4.54)\end{array}$ & $\begin{array}{l}-0.677 \\
(1.21)\end{array}$ & $\begin{array}{c}1.72 \\
(2.61)\end{array}$ \\
\hline
\end{tabular}

* Significant at $95 \%$ confidence level

** $\quad$ Significant at $99 \%$ confidence level 
Table 14: Fitted values for percentage decline in living standard upon spouse's death

\begin{tabular}{llccc}
\hline \hline & & 25th percentile & Median & 75th percentile \\
\hline Wives & Base case & -21.0 & -4.9 & 6.9 \\
& Highly vulnerable & -96.1 & -51.7 & -12.9 \\
& & & & \\
& & -21.7 & -7.3 & 3.7 \\
Secondary earners & Base case & -103.1 & -58.1 & -19.9 \\
& Highly vulnerable & & & \\
& & -3.4 & 0.2 & 2.0 \\
Husbands & Base case & -60.1 & -7.7 & -1.3 \\
& Highly vulnerable & & 0.1 & 2.9 \\
& & -3.4 & -1.2 & 0.4 \\
\hline \hline
\end{tabular}

Assumptions for base case: Joint earnings of $\$ 50,000,75 \%$ attributable to husband, assets equal to $75 \%$ of income, ages 58 (husband) and 54 (wife), no dependents, white, no college degree, no pensions, homeowners, $65 \%$ self-assessed probability of reaching age 65 (both spouses).

Assumptions for highly vulnerable case: Spouse accounts for $100 \%$ of earnings (50\% in case of primary earners), ages 52 (husband) and 48 (wife), one dependent, non-white, renter; otherwise same as base case. 


\section{References}

Auerbach, Alan J. And Laurence J. Kotlikoff, "Life Insurance of the Elderly: Its Adequacy and Determinants," in G. Burtless (ed.), Work, Health, and Income Among the Elderly, The Brookings Institution, Washington D.C., 1987.

Auerbach, Alan J. And Laurence J. Kotlikoff, "Life Insurance Inadequacy - Evidence from a Sample of Older Widows," National Bureau of Economic Research Working Paper No. 3765, 1991 la.

Auerbach, Alan J. And Laurence J. Kotlikoff, “The Adequacy of Life Insurance Purchases,” Journal of Financial Intermediation, 1(3), June 1991b, 215-241.

Bernheim, B. Douglas, "The Economic Effects of Social Security: Towards a Reconciliation of Theory and Measurement," Journal of Public Economics 33 (3), August 1987, 273-304.

Gokhale, Jagadeesh, Laurence J. Kotlikoff, and Mark Warshawsky, "Financial Planning -- The Economic vs. the Conventional Approach," mimeo, NBER working paper, 1999.

Holden, K.C., R.V. Burkhauser, and D.A. Myers, "Pensioners' Annuity Choice: Is the Well-Being of their Widows Considered?" University of Wisconsin Institute for Research on Poverty Discussion Paper 802-86, 1986.

Hurd, Michael D. and David A. Wise, "The Wealth and Poverty of Widows: Assets Before and After the Husband's Death," in D. Wise (ed.), The Economics of Aging, Chicago and London: University of Chicago Press, 1989, 177-99.

Kotlikoff, Laurence J. and Avia Spivak, “The Family as an Incomplete Annuities Market,” Journal of Political Economy, 89 (2), April 1981, 372-91.

Kotlikoff, Laurence J., What Determines Savings?, Cambridge, MA.: MIT Press, 1989

Lundberg, Shelly, "Family Bargaining and Retirement Behavior," in Henry Aaron (ed.), Behavioral Economics and Retirement Policy, Brookings Institution, 1999 (forthcoming).

Mitchell, Olivia S. and James F., Moore, "Retirement Wealth Accumulation and Decumulation: New Developments and Outstanding Opportunities," NBER working paper, no. 6178, 1997a.

Mitchell, Olivia S. and James F., Moore, "Projected Retirement Wealth and Savings Adequacy in the Health and Retirement Study," NBER working paper, no. 6240, $1997 \mathrm{~b}$.

Nelson, Julie A., “Methods of Estimating Household Equivalence Scales: An Empirical Investigation," Review of Income and Wealth, 38 (3), September 1992.

Ringen, S. "Households, Standard of Living, and Inequality," Review of Income and Wealth, 37, 1991, 1-13.

Williams, Roberton, David Weiner, and Frank Sammartino, "Equivalence Scales, the Income Distribution, and Federal Taxes," Technical Paper Series 1999-2, Congressional Budget Office, October 1998. 
Yaari, Menachem, "Uncertain Lifetime, Life Insurance, and the Theory of the Consumer," Review of Economic Studies, 32, April 1965, 137-50. 
To order any of these papers in hard copy, see instructions at the end of this list. To subscribe to all NBER Working Papers or the papers in a single area, see instructions inside the back cover

\begin{tabular}{|c|c|}
\hline Number & Author(s) \\
\hline 7319 & $\begin{array}{l}\text { Randall S. Kroszner } \\
\text { Philip E. Strahan }\end{array}$ \\
\hline 7320 & $\begin{array}{l}\text { Alan L. Gustman } \\
\text { Thomas L. Steinmeier }\end{array}$ \\
\hline 7321 & $\begin{array}{l}\text { Jagadeesh Gokhale } \\
\text { Laurence J. Kotlikoff } \\
\text { Mark J. Warshawsky }\end{array}$ \\
\hline 7322 & $\begin{array}{l}\text { Stacy Berg Dale } \\
\text { Alan B. Krueger }\end{array}$ \\
\hline 7323 & $\begin{array}{l}\text { Harry Holzer } \\
\text { David Neumark }\end{array}$ \\
\hline 7324 & $\begin{array}{l}\text { Mark McClellan } \\
\text { Douglas Staiger }\end{array}$ \\
\hline 7325 & $\begin{array}{l}\text { David Ikenberry } \\
\text { Josef Lakonishok } \\
\text { Theo Vermaelen }\end{array}$ \\
\hline 7326 & $\begin{array}{l}\text { Thomas C. Kinnaman } \\
\text { Don Fullerton }\end{array}$ \\
\hline 7327 & $\begin{array}{l}\text { Mark McClellan } \\
\text { Douglas Staiger }\end{array}$ \\
\hline 7328 & $\begin{array}{l}\text { John DiNardo } \\
\text { Mark P. Moore }\end{array}$ \\
\hline
\end{tabular}

$\underline{\text { Title }}$

Date

Bankers on Boards: Monitoring, Conflicts of Interest, $\quad 8 / 99$ and Lender Liability

Pensions and Retiree Health Benefits in Household Wealth: Changes from 1969 to 1992

Comparing the Economic and Conventional Approaches 8/99 to Financial Planning

Estimating the Payoff to Attending a More Selective College: An Application of Selection on Observables and Unobservables

Assessing Affirmative Action

Comparing Hospital Quality at For-Profit and Not-forProfit Hospitals

Stock Repurchases in Canada: Performance and Strategic 8/99 Trading

The Economics of Residential Solid Waste Management 8/99

The Quality of Health Care Providers

The Phillips Curve is Back? Using Panel Data to $8 / 99$ Analyze the Relationship Between Unemployment and Inflation in an Open Economy

Austan Goolsbee

Evidence on Learning and Network Externalities in the Diffusion of Home Computers

Time-Varying Betas and Asymmetric Effect of News:

9/99

Robert F. Engle

Empirical Analysis of Blue Chip Stocks

Modeling the Impacts of Market Activity on Bid-Ask Spreads in the Option Market

You can download these and other papers at the NBER Web site: www.nber.org

Free searchable abstracts are also available at the site. 
To order any of these papers in hard copy, see instructions at the end of this list. To subscribe to all NBER Working Papers or the papers in a single area, see instructions inside the back cover.

Number $\quad \underline{\text { Author(s) }}$

7333

7334

7335

7336

7337

7338

7340

7341

7342

7343

7344

7345

7346

7347
James L. Heckman

Rajesh K. Aggarwal Andrew A. Samwick

Rajesh K. Aggarwal Andrew A. Samwick

Richard Portes

Hélène Rey

Kathryn M. Dominguez

Jeffrey A. Frankel

Axel Börsch-Supan

Hylke Vandenbussche

Jozef Konings

Linda Springael

Robert F. Engle

Simone Manganelli

David C. King

Richard J. Zeckhauser

Christina Paxson

Jane Waldfogel

Michael Hout

Harvey S. Rosen

Jean O. Lanjouw

Mark Schankerman

Geert Bekaert

Steven R. Grenadier

Thomas N. Hubbard
Title

$\underline{\text { Date }}$

Causal Parameters and Policy Analysis in Economics: $\quad 9 / 99$

A Twentieth Century Retrospective

Performance Incentives Within Firms: The Effect of $9 / 99$

Managerial Responsibility

Empire-Builders and Shirkers: Investment, Firm

Performance, and Managerial Incentives

The Determinants of Cross-Border Equity Flows

The Market Microstructure of Central Bank Intervention 9/99

No Single Currency Regime is Right for all Countries $\quad 9 / 99$ or at All Times

Incentive Effects of Social Security Under an Uncertain $\quad 9 / 99$

Disability Option

Import Diversion under European Antidumping Policy

$9 / 99$

CAViaR: Conditional Value at Risk By Quantile

$9 / 99$

Regression

Congressional Vote Options

$9 / 99$

Work, Welfare, and Child Maltreatment

Self-Employment, Family Background, and Race

$9 / 99$

The Quality of Ideas: Measuring Innovation with Multiple Indicators

Stock and Bond Pricing in an Affine Economy

$9 / 99$

How Wide Is the Scope of Hold-Up-Based Theories? Contractual Form and Market Thickness in Trucking

You can download these and other papers at the NBER Web site:

Free searchable abstracts are also available at the site. 
To order any of these papers in hard copy, see instructions at the end of this list. To subscribe to all NBER Working Papers or the papers in a single area, see instructions inside the back cover.

\begin{tabular}{|c|c|}
\hline Number & Author(s) \\
\hline 7348 & Jonathan Gruber \\
\hline 7349 & Edward P. Lazear \\
\hline 7350 & Tamim Bayoumi \\
\hline 7351 & $\begin{array}{l}\text { Taizo Motonishi } \\
\text { Hiroshi Yoshikawa }\end{array}$ \\
\hline 7352 & $\begin{array}{l}\text { Daron Acemoglu } \\
\text { Robert Shimer }\end{array}$ \\
\hline 7353 & $\begin{array}{l}\text { Jeff Grogger } \\
\text { Charles Michalopoulos }\end{array}$ \\
\hline 7354 & Roberto Rigobon \\
\hline 7355 & $\begin{array}{l}\text { Ricardo J. Caballero } \\
\text { Mohamad L. Hammour }\end{array}$ \\
\hline 7356 & $\begin{array}{l}\text { Alec Ian Gershberg } \\
\text { Michael Grossman } \\
\text { Fred Goldman }\end{array}$ \\
\hline 7357 & Robert E. Lipsey \\
\hline 7358 & Vernon Henderson \\
\hline 7359 & $\begin{array}{l}\text { lain Cockburn } \\
\text { Rebecca Henderson } \\
\text { Scott Stern }\end{array}$ \\
\hline 7360 & $\begin{array}{l}\text { Douglas Holtz-Eakin } \\
\text { John W. Phillips } \\
\text { Harvey S. Rosen }\end{array}$ \\
\hline 7361 & $\begin{array}{l}\text { Bong-Chan Kho } \\
\text { René M. Stulz }\end{array}$ \\
\hline 7362 & $\begin{array}{l}\text { Jagadeesh Gokhale } \\
\text { Laurence J. Kotlikoff }\end{array}$ \\
\hline
\end{tabular}

Title

Date

The Wealth of the Unemployed: Adequacy and $9 / 99$ Implications for Unemployment Insurance

Educational Production $9 / 99$

The Morning After: Explaining the Slowdown in Japanese Growth in the 1990s

Causes of the Long Stagnation of Japan during the 1990's: Financial or Real?

Productivity Gains From Unemployment Insurance

Welfare Dynamics under Time Limits $9 / 99$

On the Measurement of the International Propagation $9 / 99$ of Shocks

The Cost of Recessions Revisited: A ReverseLiquidationist View

Competition and the Cost of Capital Revisited: Special $9 / 99$ Authorities and Underwriters in the Market for Taxexempt Hospital Bonds

Foreign Production by U.S. Firms and Parent Firm Employment

Marshall's Economies $9 / 99$

The Diffusion of Science-Driven Drug Discovery: Organizational Change in Pharmaceutical Research

Free searchable abstracts are also available at the site. 
To order any of these papers in hard copy, see instructions at the end of this list. To subscribe to all NBER Working Papers or the papers in a single area, see instructions inside the back cover.

\begin{tabular}{|c|c|}
\hline$\underline{\text { Number }}$ & Author(s) \\
\hline 7363 & $\begin{array}{l}\text { Bruce D. Meyer } \\
\text { Dan T. Rosenbaum }\end{array}$ \\
\hline 7364 & $\begin{array}{l}\text { Dani Rodrik } \\
\text { Andrés Velasco }\end{array}$ \\
\hline 7365 & $\begin{array}{l}\text { Michael D. Bordo } \\
\text { Lars Jonung }\end{array}$ \\
\hline 7366 & Emmanuel Saez \\
\hline 7367 & Emmanuel Saez \\
\hline 7368 & $\begin{array}{l}\text { Alan L. Gustman } \\
\text { Thomas L. Steinmeier }\end{array}$ \\
\hline 7369 & $\begin{array}{l}\text { Wolfgang Keller } \\
\text { Arik Levinson }\end{array}$ \\
\hline 7370 & $\begin{array}{l}\text { Michael Baker } \\
\text { Gary Solon }\end{array}$ \\
\hline 7371 & $\begin{array}{l}\text { Michael Baker } \\
\text { Nicole M. Fortin }\end{array}$ \\
\hline 7372 & $\begin{array}{l}\text { B. Douglas Bernheim } \\
\text { Lorenzo Forni } \\
\text { Jagadeesh Gokhale } \\
\text { Laurence J. Kotlikoff }\end{array}$ \\
\hline
\end{tabular}

Title

Date

Welfare, the Earned Income Tax Credit, and the

Labor Supply of Single Mothers

Short-Term Capital Flows

$9 / 99$

The Future of EMU: What Does the History of

Monetary Unions Tell Us?

Do Taxpayers Bunch at Kink Points?

$9 / 99$

The Effect of Marginal Tax Rates on Income: A Panel $\quad 9 / 99$ Study of 'Bracket Creep'

What People Don't Know About Their Pensions and Social Security: An Analysis Using Linked Data From The Health and Retirement Study

Environmental Compliance Costs and Foreign Direct Investment Inflows to U.S. States

Earnings Dynamics and Inequality among Canadian Men, 9/99 1976-1992: Evidence from Longitudinal Income Tax Records

Occupational Gender Composition and Wages in Canada: 9/99 1987-1988

The Adequacy of Life Insurance: Evidence from the $10 / 99$ Health and Retirement Survey

Copies of the above working papers can be obtained for $\$ 10.00$ per copy (plus $\$ 10.00$ per order for shipping for all locations outside the continental U.S.) to Working Papers, NBER, 1050 Massachusetts Avenue, Cambridge, MA 021385398. Pre-payment is required on all orders and may be made by check or credit card. Checks should be made payable to the NBER and must be in dollars drawn on a U.S. bank. If paying by credit card, include the cardholder's name, account number, and expiration date. For all orders, please be sure to include your return address and telephone number. Working papers may also be ordered by telephone (868-3900), fax (617-868-2742), or email (orders@nber.org).

\section{You can download these and other papers at the NBER Web site: www.nber.org}

Free searchable abstracts are also available at the site. 